\title{
Side effects and accounting aspects of hypothetical large-scale Southern Ocean iron fertilization
}

\author{
A. Oschlies ${ }^{1}$, W. Koeve ${ }^{1}$, W. Rickels ${ }^{2}$, and K. Rehdanz ${ }^{2}$ \\ ${ }^{1}$ IFM-GEOMAR, Leibniz-Institut für Meereswissenschaften, Kiel, Düsternbrooker Weg 20, 24105 Kiel, Germany \\ ${ }^{2}$ Kiel Inst. for the World Economy at the Christian-Albrechts Univ. of Kiel, Hindenburgufer 66, 24105, Kiel, Germany
}

Received: 1 April 2010 - Published in Biogeosciences Discuss.: 26 April 2010

Revised: 2 December 2010 - Accepted: 10 December 2010 - Published: 17 December 2010

\begin{abstract}
Recent suggestions to slow down the increase in atmospheric carbon dioxide have included ocean fertilization by addition of the micronutrient iron to Southern Ocean surface waters, where a number of natural and artificial iron fertilization experiments have shown that low ambient iron concentrations limit phytoplankton growth. Using a coupled carbon-climate model with the marine biology's response to iron addition calibrated against data from natural iron fertilization experiments, we examine biogeochemical side effects of a hypothetical large-scale Southern Ocean Iron Fertilization (OIF) that need to be considered when attempting to account for possible OIF-induced carbon offsets. In agreement with earlier studies our model simulates an OIF-induced increase in local air-sea $\mathrm{CO}_{2}$ fluxes by about $73 \mathrm{GtC}$ over a 100 -year period, which amounts to about $48 \%$ of the OIFinduced increase in organic carbon export out of the fertilized area. Offsetting $\mathrm{CO}_{2}$ return fluxes outside the region and after stopping the fertilization at 1, 7, 10, 50, and 100 years are quantified for a typical accounting period of 100 years. For continuous Southern Ocean iron fertilization, the $\mathrm{CO}_{2}$ return flux outside the fertilized area cancels about $20 \%$ of the fertilization-induced $\mathrm{CO}_{2}$ air-sea flux within the fertilized area on a 100-yr timescale. This "leakage" effect has a radiative impact more than twice as large as the simulated enhancement of marine $\mathrm{N}_{2} \mathrm{O}$ emissions. Other side effects not yet discussed in terms of accounting schemes include a decrease in Southern Ocean oxygen levels and a simultaneous shrinking of tropical suboxic areas, and accelerated ocean acidification in the entire water column in the Southern Ocean at the expense of reduced globally-averaged surface-
\end{abstract}

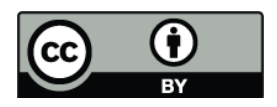

Correspondence to: A. Oschlies (aoschlies@ifm-geomar.de) water acidification. A prudent approach to account for the OIF-induced carbon sequestration would account for global air-sea $\mathrm{CO}_{2}$ fluxes rather than for local fluxes into the fertilized area only. However, according to our model, this would underestimate the potential for offsetting $\mathrm{CO}_{2}$ emissions by about $20 \%$ on a 100 year accounting timescale. We suggest that a fair accounting scheme applicable to both terrestrial and marine carbon sequestration has to be based on emission offsets rather than on changes in individual carbon pools.

\section{Introduction}

While reduction of $\mathrm{CO}_{2}$ emissions must be the ultimate strategy to address the imminent global warming threat, carbon sequestration may help to offset emissions prior to society implementing the necessary infrastructural changes to a much lower $\mathrm{CO}_{2}$ emission world. Even for the unlikely case of drastic emission cuts it is not certain that dangerous climate change can be avoided. Estimated probability distributions of essential parameters such as the climate sensitivity to increasing atmospheric $\mathrm{CO}_{2}$ are not yet reliable enough to exclude scenarios that lie well outside the envelopes of currently projected climate changes.

Given the large uncertainties in current climate projections, we cannot rule out situations in which climate engineering may emerge as a last resort for trying to avoid dangerous climate change. Basically, climate engineering can be classified into solar radiation management and $\mathrm{CO}_{2}$ sequestration. Solar radiation management can generate fast climate response (and may thereby seem appealing as emergency procedure), but does not immediately address the cause of the problem and could potentially allow regional

Published by Copernicus Publications on behalf of the European Geosciences Union. 
regulation of its efficiency. Carbon sequestration, however, is expected to take longer to have significant climate impacts, but directly addresses the cause of the problem and, because of the well-mixed state of the atmospheric $\mathrm{CO}_{2}$ pool, will be of globally uniform intensity. In the interest of equity and the common good of a reduction in atmospheric $\mathrm{CO}_{2}$ increase, one might hence favor carbon sequestration over solar radiation management, provided that such measures can at all be agreed upon well ahead of events considered as dangerous climate change. As the atmosphere does not distinguish between a reduction of $\mathrm{CO}_{2}$ emissions and $\mathrm{CO}_{2}$ sequestration, it is in our view legitimate if not mandatory to explore the possible benefits and risks of such options before potential climate threats are imminent and "slow" climate engineering options drop out (Güssow et al., 2010). At this stage, this holds in particular for modeling studies, which do not pose any immediate risks to the environment, but can provide valuable insights into possible feedbacks in the Earth system.

Basically, we can distinguish the terrestrial carbon sink that may, for example, be enhanced by forestation, and the oceanic sink that can probably be enhanced by iron fertilization. While the terrestrial carbon sink has entered the Kyoto Protocol, the oceanic sink has not. Partitioning of carbon among the ocean and the atmosphere, with its current ratio of about $60: 1$, is controlled by both the temperaturedependent solubility of $\mathrm{CO}_{2}$ (the solubility pump) and the photosynthetic conversion of dissolved inorganic carbon into particulate organic carbon that can sink away from immediate contact with the atmosphere (the biological pump). Whereas the oceanic uptake of about $40 \%$ of the historical anthropogenic $\mathrm{CO}_{2}$ emissions is thought to have occurred predominantly via the solubility pump (Sabine et al., 2004), proposed oceanic carbon-sequestration schemes have concentrated mostly on possible enhancements of the biological pump.

In addition to carbon and light, phytoplankton needs nutrients to grow. These include the macronutrients nitrate and phosphate (for some species also silicate), which are usually required in micromolar concentrations, and a number of micronutrients of which much lower concentrations are needed (nanomolar in the case of iron). Because of the large quantities of fertilizer required (typically, one gram ammonia is needed to fix five grams of carbon), fertilization by adding allochthonous macronutrients is not usually considered feasible at large scales.

Fertilization may be more practicable for micronutrients, which are required in quantities several orders of magnitude smaller than those of macronutrients. Successful fertilization with micronutrients, the most prominent one being iron, requires that unused macronutrients are present in the light-lit surface waters. This is the case in so-called High Nutrient Low Chlorophyll (HNLC) areas of the ocean (Martin and Fitzwater, 1988).
A number of in situ iron fertilization experiments have demonstrated enhanced biological production upon the addition of iron in all major HNLC areas, i.e., the Southern Ocean, the equatorial Pacific, and the subpolar North Pacific (de Baar et al., 2005; Boyd et al., 2007). Despite the observed drawdown of surface $p \mathrm{CO}_{2}$ upon iron fertilization, the short (few weeks) duration of these experiments did only in few cases allow the direct observation of enhanced export from the surface layer (Bishop et al., 2004; Boyd et al., 2005). However, continuous natural iron fertilization at the Kerguelen Plateau and Crozet Islands in the Southern Ocean show that export fluxes there are two to three times larger than in the adjacent unfertilized regions (Blain et al., 2007; Pollard et al., 2009). Modeling studies using ocean-only models suggest that iron fertilization has a limited impact on net $\mathrm{CO}_{2}$ air-sea fluxes when applied in the equatorial Pacific (Sarmiento and Orr, 1991; Gnanadesikan et al., 2003), but may lead to a drawdown of atmospheric $\mathrm{CO}_{2}$ by some 33 to $75 \mu \mathrm{atm}$ when carried out at large scale over the Southern Ocean (Aumont and Bopp, 2006).

We here extend earlier ocean-only model studies to an Earth System model that contains fully interactive oceanic, atmospheric, and terrestrial carbon pools as well as oxygen and nitrous oxide as prognostic variables. The aim of this study is to assess the quality of biogeochemical side effects and their relevance for potential future accounting schemes. These will be needed should iron fertilization ever be deemed suitable for consideration in a Post-Kyoto climate agreement. Following the current political decision to restrict any accounting to a 100 year time scale (UNFCCC, 1997), we also focus on this time scale in this study. We nevertheless find it mandatory that longer term impacts are investigated and carefully assessed before starting any large-scale Ocean Iron Fertilization (OIF).

The paper is organized as follows: After a brief description of the numerical carbon-climate model and our pragmatic parameterization of iron fertilization in Sect. 2, we investigate local and remote biogeochemical impacts of a hypothetical large-scale Southern-Ocean iron fertilization in Sect. 3. Accounting aspects are discussed in Sect. 4 before the paper ends with a concluding section. The implications for different assignment options for carbon credits are discussed in a separate study (Rickels et al., 2010).

\section{Model experiments}

The model used is the University of Victoria (UVic) Earth System Climate Model (Weaver et al., 2001) in the configuration described by Schmittner et al. (2008). The oceanic component is a fully three-dimensional primitive-equation model with nineteen levels in the vertical ranging from $50 \mathrm{~m}$ thickness near the surface to $500 \mathrm{~m}$ in the deep ocean. It contains a simple marine ecosystem model with the two major nutrients nitrate and phosphate and two phytoplankton classes, 
nitrogen fixers and other phytoplankton, with the former being limited only by phosphate. Organic matter is produced, processed, and remineralized according to a fixed elemental stoichiometry of C:N:P=112:16:1. Detritus sinks with a sinking velocity increasing linearly with depth from $7 \mathrm{~m} /$ day at the surface to $40 \mathrm{~m} /$ day at $1000 \mathrm{~m}$ depth and constant below. The production of calcium carbonate is assumed proportional to the production of nondiazotrophic detritus and its instantaneous export and dissolution is parameterized by an e-folding depth of $3500 \mathrm{~m}$. The ocean component is coupled to a single-level energy-moisture balance model of the atmosphere and a dynamic-thermodynamic sea ice component. The terrestrial vegetation and carbon cycle component is based on the Hadley Centre's TRIFFID model (Cox et al., 2000). All model components use a common horizontal resolution of $1.8^{\circ}$ latitude $\times 3.6^{\circ}$ longitude. After a spin up of more than 10000 years under pre-industrial atmospheric and astronomical boundary conditions, the model is run under historical conditions from year 1765 to 2000 using fossil-fuel and land-use carbon emissions as well as solar, volcanic and anthropogenic aerosol forcings. From year 2000 to 2100 , the model is forced by $\mathrm{CO}_{2}$ emissions following the SRES A2 non-intervention scenario that assumes high population growth and moderate and uneven economic growth, leading to an increase from today's emissions of about $8 \mathrm{GtC} / \mathrm{yr}$ to about $29 \mathrm{GtC} / \mathrm{yr}$ in the year 2100 . After 2100 , annual emissions are assumed to decline by $1.45 \mathrm{GtC}$ per year and would reach zero at year 2300 .

Because of the difficulties inherent in explicitly modeling the complex iron chemistry and its interaction with the marine biology, marine biogeochemical models have to rely on empirical parameterizations of the relevant iron effects. In one of the most complex iron models developed so far (Weber et al., 2007), we had attempted to model the upper ocean iron cycle at the Bermuda Atlantic Time-series Study site by resolving several processes such as colloidal aggregation and scavenging, organic complexation by ligands, and photochemical reactions. It turned out that such a complex model could not be constrained well enough to become sufficiently robust for extrapolation to other regions of the ocean. In our current application of a global model, we therefore resort to a pragmatic modeling approach and include the effect of iron on phytoplankton growth rates only implicitly. Focusing on long-term effects of a hypothetical large-scale iron fertilization scheme, our parameterization of large-scale iron fertilization was accordingly calibrated against the changes in export production observed for the persistent natural iron fertilization at the Kerguelen Plateau and Crozet Islands in the Southern Ocean (Blain et al., 2007; Pollard et al., 2009).

Although the pragmatic model does not include an explicit parameterization of the iron cycle, it could nevertheless be tuned to achieve a reasonable fit to observed biogeochemical tracer distributions, in particular by using a low phytoplankton growth rate that allows for the persistence of HNLC areas (Schmittner et al., 2008; Oschlies et al., 2008). The

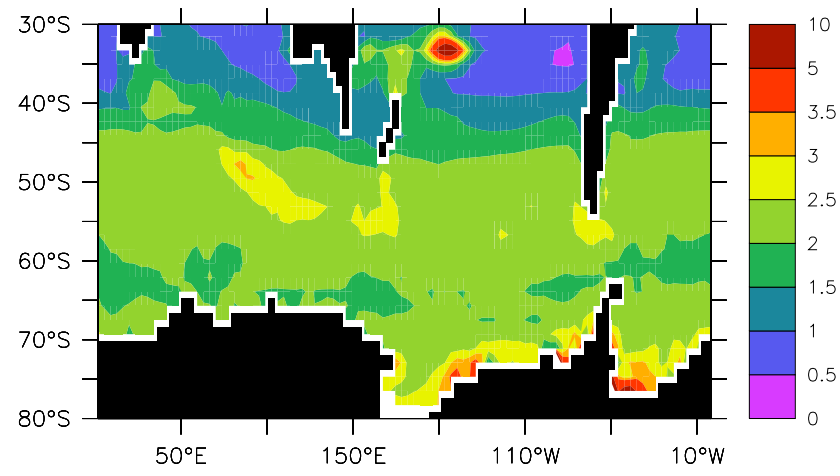

Fig. 1. Ratio of the particulate carbon export across $z=125 \mathrm{~m}$ simulated by the fertilization experiment in year 2011 (first year of fertilization) and the control experiment in the same year.

effect of ocean iron fertilization is simulated by doubling the phytoplankton maximum growth rate from 0.13 day $^{-1}$ to 0.26 day $^{-1}$ (at $0^{\circ} \mathrm{C}$ ) over the fertilized area and during the fertilization period. Increasing the maximum growth rate mimics the effect of iron in relaxing light limitation (Sunda and Huntsman, 1997), and the factor-2 enhancement results in an increase in simulated carbon export across $z=125 \mathrm{~m}$ by a factor 2 to 3 with respect to an unfertilized control experiment (Fig. 1). This is in good agreement with the impact of natural iron fertilization near Kerguelen and Crozet Islands, where Blain et al. (2007) and Pollard et al. (2009) estimated particulate carbon export fluxes two to three times higher than in the adjacent unfertilized regions. Since we cannot fully rule out that the natural iron fertilization is not saturating and that artificial fertilization could be engineered to have an even larger impact, we also performed sensitivity experiments with maximum phytoplankton growth rates enhanced by factors of 3 and 5 and, in an attempt to simulate an upper bound of possible OIF impacts, to a hypothetical very high value of $10 \mathrm{day}^{-1}$. None of these experiments showed complete depletion of macronutrients in the fertilized area (Appendix, Fig. A1). While the main text of the paper considers only the conservative factor- 2 enhancement obtained from tuning the model against the natural iron fertilization experiments, the results of the sensitivity studies are presented briefly in the Appendix as hypothetical upper limits of iron fertilization impacts.

There are at least two potential caveats of our approach of increasing the phytoplankton maximum growth rate to mimic the effects of iron fertilization: First, there may be relevant physiological responses to iron addition other than an increase in the maximum growth rate. Second, our approach does not allow keeping track of the added iron and implicitly assumes that the added iron is not recycled and therefore not available for secondary fertilization outside the fertilized area. To address the first caveat, we note that the physiological role of iron in the electron transport pathways involved in photosynthesis suggests that phytoplankton cells 
replete in iron can utilize light more efficiently (Strzepek and Harrison, 2004). Iron stress has been found to decrease the chlorophyll-to-carbon ratio, presumably because of the requirement for iron in chlorophyll synthesis (Sunda and Huntsman, 1997). Iron seems also required for the reduction of nitrate to ammonia (Raven, 1990; Sunda and Huntsman, 1997).

Our approach of simulating the effects of iron fertilization by an increase in the maximum growth rate (i.e., light saturated growth) can be regarded as an attempt to represent both the need for iron in proteins that mediate photosynthetic electron transport and thereby determine the maximum yield of electrons for photosynthesis when light is abundant, and also the effect of iron on non-photosynthetic processes such as nitrate reduction (Galbraith et al., 2010). As pointed out by Galbraith et al. (2010), if applied to iron limitation in general, our parameterization of iron effects on the maximum growth rate makes light limitation less likely under severe iron stress. To counteract this tendency, they suggested to make the initial slope $\alpha$ and also the chlorophyll-to-carbon ratio increasing functions with iron. Field data from the Southern Ocean, however, show little relationship of $\alpha$ with iron availability, and iron addition experiments also reveal a dominant impact on the maximum growth rate with relatively little changes in $\alpha$ (Hopkinson et al., 2007). Sensitivity experiments we performed with our model in which $\alpha$ was varied by up to a factor of 100 in the fertilized Southern Ocean region showed very little effect, indicating a - for our model - relatively abrupt switch from severe light limitation in winter to very little light limitation in the high-latitude summers.

The second caveat of not keeping track of the added iron depends on the lifetime of the added iron in bioavailable form, which is still poorly known and requires further research (Boyd and Ellwood, 2010). Differences between observed iron and macronutrient profiles indicate iron-removal timescales considerably faster than circulation timescales. Moreover, hydrographic sections underneath the Saharan dust plume (Measures et al., 2008) suggest that newly added iron cannot substantially increase concentrations of dissolved iron on circulation time scales. The issue of iron retention timescales has recently been explored by Sarmiento et al. (2010) who performed an "iron added and removed" simulation and compared it against results of an explicit iron chemistry model. According to their model, the retention of iron in the model has very little effect on the fertilizationinduced carbon uptake per fertilization-induced export production (although the fertilization-induced export production per added iron was up to a factor 20 smaller in the "iron added and removed" simulation). Having calibrated our model against observational estimates of fertilizationinduced export production, we are confident that even a currently available explicit model of iron chemistry would not significantly change our estimates of fertilization-induced marine carbon uptake.
Our pragmatic approach of enhancing the maximum phytoplankton growth rate is intermediate between earlier studies that assumed a complete surface macronutrient depletion (e.g., Sarmiento and Orr, 1991; Gnanadesikan et al., 2003) and the increase in growth rates from models with an explicit representation of iron and a parameterization of its control on phytoplankton growth (e.g., Aumont and Bopp, 2006; Jin et al., 2008). The more explicit parameterisation of (patchy) iron fertilization in the Southern Ocean used by Aumont and Bopp (2006) revealed a similar increase in (local) export production by a factor 2-4 (their Figure 5d). In the different experiments performed for this study, fertilization is applied for $1,7,10,50$, and 100 consecutive years, respectively. All experiments start the fertilization in year 2011. For reference we note that due to a bug in an earlier code version used for the unfertilized reference simulation in the Biogeosciences Discussion version of this paper, some of the numbers in the tables and in the text have changed with respect to the Discussion paper. This had no significant impact on simulated nutrient or oxygen fluxes or globally-averaged $\mathrm{CO}_{2}$ fluxes, but it affected the latitudinal partitioning of air-sea $\mathrm{CO}_{2}$ fluxes. All figures and numbers presented in this paper were computed with the corrected code version available at http://climate.uvic.ca/model/2.8/.

\section{Impacts}

In this section we investigate the impacts of simulated Southern Ocean iron fertilization on various biogeochemical variables and fluxes. With consideration of the subsequent discussion of accounting aspects, we distinguish between local effects in the fertilized region and global impacts that include the remote effects outside the fertilized area.

\subsection{Macronutrients}

\subsubsection{Local impacts}

Simulated Southern Ocean surface nitrate concentrations of the unfertilized control run agree well with observed values (Fig. 2a), except for the seasonally ice-covered region south of $65^{\circ} \mathrm{S}$, where observations are biased towards lower summer values. In the first fertilization year, simulated surface macronutrients show the largest decrease by $3-4 \mathrm{mmol} \mathrm{NO}_{3} \mathrm{~m}^{-3}$ between $42^{\circ} \mathrm{S}$ and $65^{\circ} \mathrm{S}$, and they decline by another $3-4 \mathrm{mmol} \mathrm{NO}_{3} \mathrm{~m}^{-3}$ in subsequent years. Macronutrient consumption by simulated OIF becomes smaller as one moves south, where light levels get lower for a longer time of the year. The maximum fertilizationinduced drawdown of $10 \mathrm{mmol} \mathrm{m}^{-3}$ is reached just north of $50^{\circ} \mathrm{N}$ in the final year of the 100 -year long continuous fertilization. While simulated OIF enhances phytoplankton growth predominantly during the summer months, the amplitude of the seasonal cycle in surface nitrate concentrations increases under simulated OIF (Fig. 2b). The amplitude in 

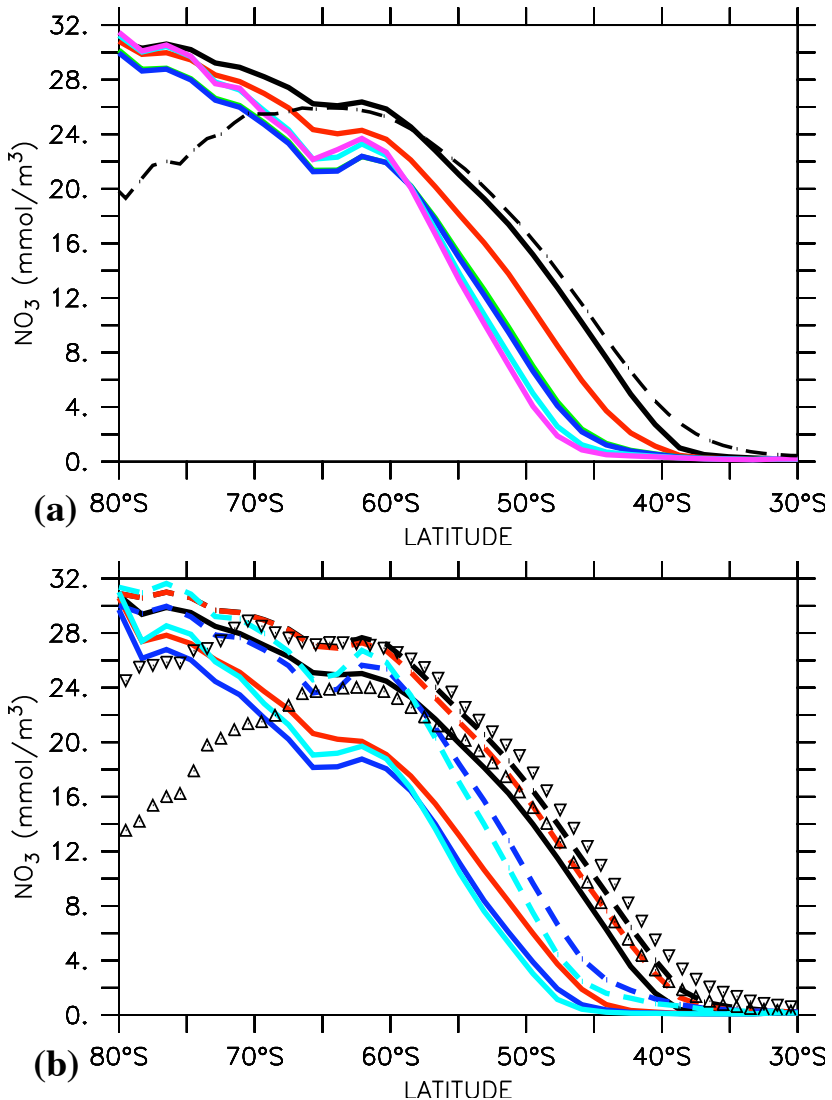

Fig. 2. (a) Zonally averaged simulated annual-mean surface nutrients in the control run (solid black) and in the World Ocean Atlas (Conkright et al., 2002) (dashed black line). Colored lines refer to model fields after 1 year of OIF (red), 7 years (green), 10 years (blue), 50 years (cyan), and 100 years (magenta) of continuous OIF south of $30^{\circ} \mathrm{S}$. (b) Maximum (dashed) and minimum (solid) zonally averaged nitrate concentrations during the annual cycle in year 2010 of the reference experiment (black) and in the 1st year (red), 10th year (blue), and 50th year (cyan) of the continuous OIF experiment. Respective maximum and minimum values from the World Ocean Atlas are depicted as downward and upward pointing triangles, respectively. Units are $\mathrm{mmol} \mathrm{m}^{-3}$.

the seasonal cycle of surface nitrate concentrations amounts to about $3 \mathrm{mmol} \mathrm{m}^{-3}$ in the control run and also in the World Ocean Atlas data between about $35^{\circ} \mathrm{S}$ and $70^{\circ} \mathrm{S}$, and it increases to about $7 \mathrm{mmol} \mathrm{m}^{-3}$ in year 10 of the OIF experiment. South of about $45^{\circ} \mathrm{S}$, a substantial stock of unutilized macronutrients is present all-year round even in the fertilization run.

\subsubsection{Remote impacts}

With more nutrients trapped underneath the fertilized surface area as a result of export and remineralization (Fig. 3a), less nutrient are available outside this region. The signal of this "nutrient robbing" (Royal Society, 2009) is exported out of the Southern Ocean via the Subpolar Mode Waters (SPMW)
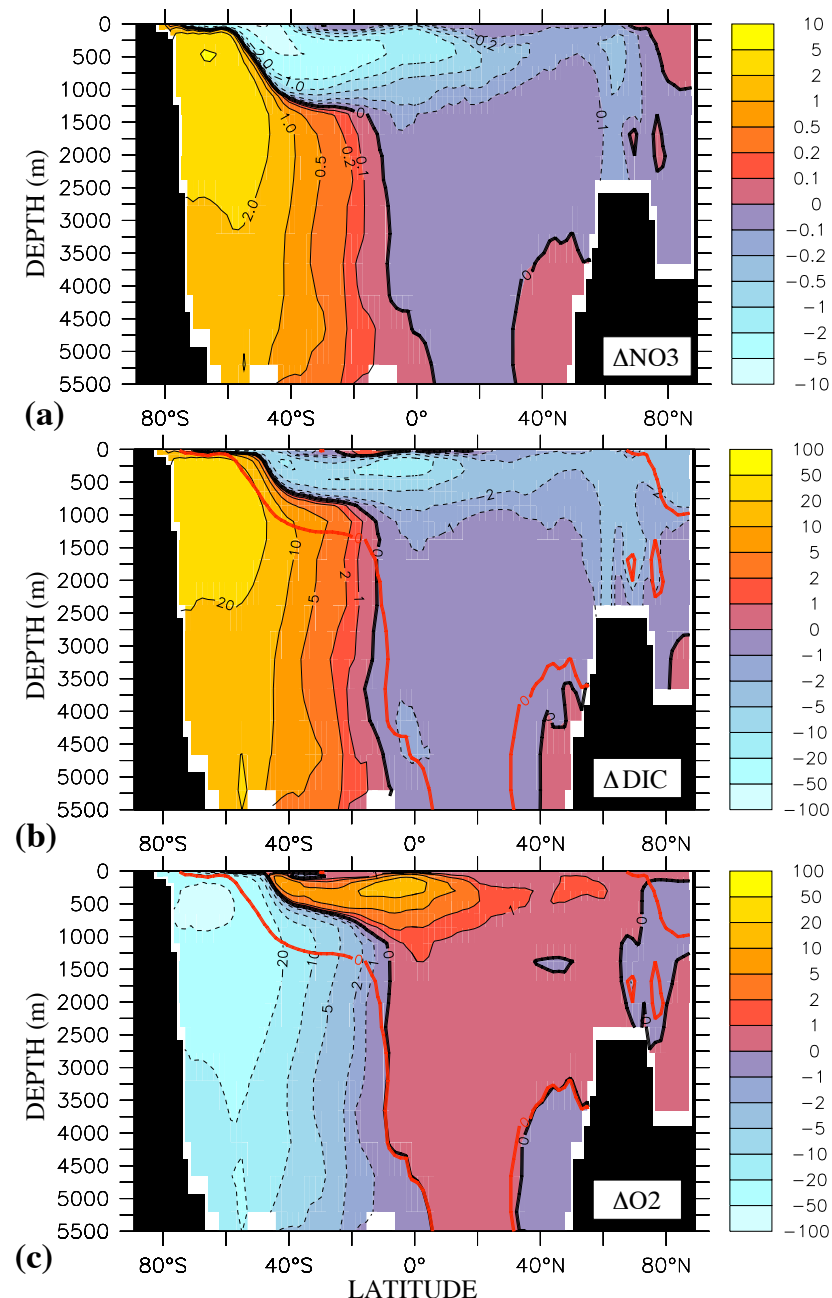

Fig. 3. Zonally averaged change in (a) simulated annual-mean nitrate concentrations, (b) simulated annual-mean dissolved inorganic carbon concentration, and (c) dissolved oxygen concentrations of the 100-year OIF run minus control run in year 2110. Units are $\mathrm{mmol} \mathrm{m}{ }^{-3}$. The red lines in (b) and (c) denote the zero nitratechange isoline of (a).

and the Antarctic Intermediate Water (AAIW), visible in Fig. 3a as a tongue of reduced nitrate concentrations moving north within the top $1200 \mathrm{~m}$. Zonally averaged subsurface nitrate concentrations drop by about $0.5 \mathrm{mmol} \mathrm{m}^{-3}$ in the core of this tongue at the equator by year 2110 . This leads to reduced nitrate supply to the tropical surface waters and reduced export production there (see below), eventually reducing nitrate concentrations at greater depth. Part of the OIFinduced nitrate deficit even reaches the formation region of North Atlantic Deep Water north of $60^{\circ} \mathrm{N}$ on the centennial time scale considered here. A similar fertilization-induced reduction in downstream nutrients and biological production has been reported previously (Sarmiento and Orr, 1991; Gnanadesikan et al., 2003). 


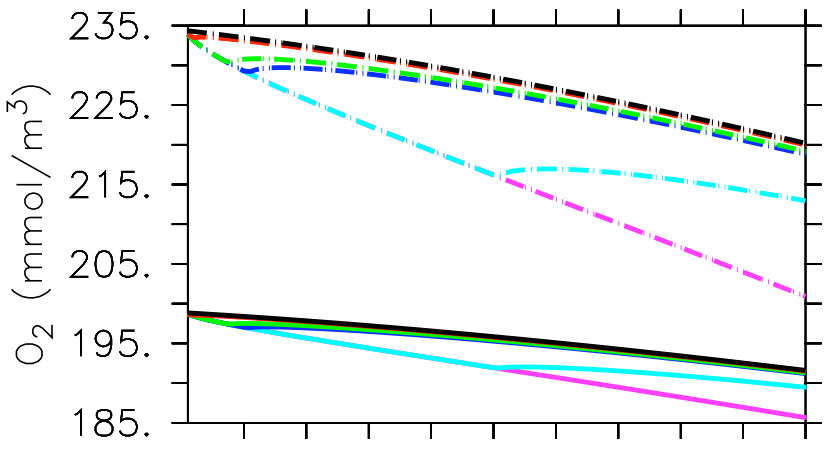

(a) $2020 \quad 2040 \quad 2060 \quad 2080 \quad 2100$

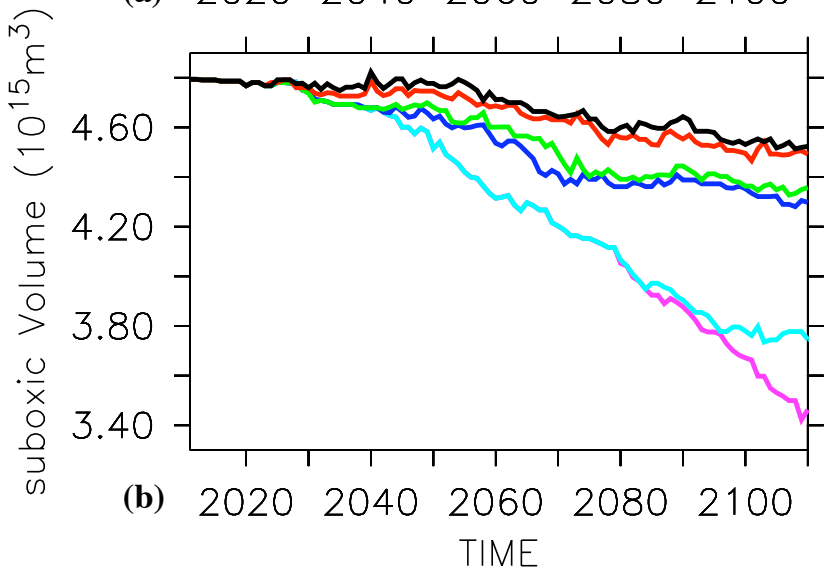

Fig. 4. (a) Simulated oxygen concentrations averaged over the fertilized area (south of $30^{\circ} \mathrm{S}$ - dashed lines - and globally - solid lines. (b) Simulated global-ocean suboxic volume, defined by oxygen concentrations lower than $5 \mathrm{mmol} \mathrm{m}^{-3}$. Colored lines refer to model fields after 1 year of OIF (red), 7 years (green), 10 years (blue), 50 years (cyan), and 100 years (magenta) of continuous OIF south of $30^{\circ} \mathrm{S}$.

\subsection{Oxygen}

\subsubsection{Local impacts}

OIF-induced changes in simulated oxygen concentrations closely mirror those of simulated nitrate concentrations (Fig. 3). In the model, both tracers are related through a constant molar $\mathrm{O}_{2}: \mathrm{N}$ ratio of 10.6 in oxic areas and away from the surface layer where oxygen is exchanged with the atmosphere (which explains why the zero $\Delta \mathrm{O}_{2}$ isocontour in Fig. $3 \mathrm{c}$ is at shallower depth than the zero $\Delta \mathrm{NO}_{3}$ isocontour in Fig. 3a). Zonally averaged oxygen concentrations drop by as much as $60 \mathrm{mmol} \mathrm{m}^{-3}$ between about 300 and $500 \mathrm{~m}$ depth south of $60^{\circ} \mathrm{S}$. Background oxygen levels in these waters are about $300 \mathrm{mmol} \mathrm{m}^{-3}$ so that waters remain well oxygenated. In the control run, mean oxygen concentrations south of $30^{\circ} \mathrm{S}$ drop by about $6 \%$ from 2010 to 2110 (black dashed curve in Fig. 4a) due to decreasing solubility under global warming as well as a slight intensification of export production in this area (see below). Continuous OIF leads to another drop by about $9 \%$ by the year 2110 . Simulated minimum oxygen concentrations south of $30^{\circ} \mathrm{S}$ decrease from $130 \mathrm{mmol} \mathrm{m}^{-3}$ in year 2010 to $119 \mathrm{mmol} \mathrm{m}^{-3}$ and $117 \mathrm{mmol} \mathrm{m}^{-3}$ in year 2110 for the control run and the continuous OIF run, respectively. On the space scales resolved by our model, Southern Ocean waters remain well oxygenated even under large-scale simulated OIF on centennial time scales.

\subsubsection{Remote impacts}

Remineralization and associated oxygen consumption are reduced and oxygen concentrations tend to increase relative to the control run outside the fertilized area (Fig. 3c). The decline in globally averaged oxygen concentrations is therefore smaller than the decline in Southern Ocean oxygen concentrations (Fig. 4a) as already noted by Sarmiento and Orr (1991). OIF-induced increases in dissolved oxygen are largest in the tropical oceans where they exceed $10 \mathrm{mmol} \mathrm{m}^{-3}$ in the zonal average. In consequence, the volume of suboxic waters $\left(\mathrm{O}_{2}<5 \mathrm{mmol} \mathrm{m}^{-3}\right)$, which our model simulates relatively well (Oschlies et al., 2008), declines by some $25 \%$ in the continuous OIF simulation by the year 2110 (Fig. 4b). Irrespective of the duration of the simulated iron fertilization, the suboxic volume starts to decrease about 2 decades after the onset of OIF, once the OIF-influenced mode waters reach the tropical oceans (Fig. 4b). Thereafter, the suboxic volume stays lower than that simulated by the control run for many decades, even when fertilization is stopped already after one year.

\subsection{Export production}

\subsubsection{Local impacts}

The simulated export production, computed as particulate organic carbon export across $z=125 \mathrm{~m}$, increases from about $2.8 \mathrm{GtC} / \mathrm{yr}$ south of $30^{\circ} \mathrm{S}$ in year 2010 of the control run to $5.4 \mathrm{GtC} / \mathrm{yr}$ in the first year of the fertilization (dashed lines in Fig. 5a). Fertilization-induced export production is largest in the first year of the fertilization when previously unutilized macronutrients can suddenly be taken up by the photosynthetically enhanced marine biota. Consumption and subsequent export results in a net downward transport of macronutrients, reducing the amount of macronutrients available for the marine biology particularly in the less light-limited northern region of the fertilized area in subsequent years (see above, Fig. 2). Under continuous OIF, simulated Southern Ocean export production reaches a relatively stable value of $4.3 \mathrm{GtC} / \mathrm{yr}$ within a few decades. The cumulative OIFinduced local export production amounts to $154 \mathrm{GtC}$ by the year 2110 (Fig. 5b).

Simulated local export production falls below levels of the control simulation in the years following a stop of simulated iron fertilization. In the model, this abrupt decline is due 


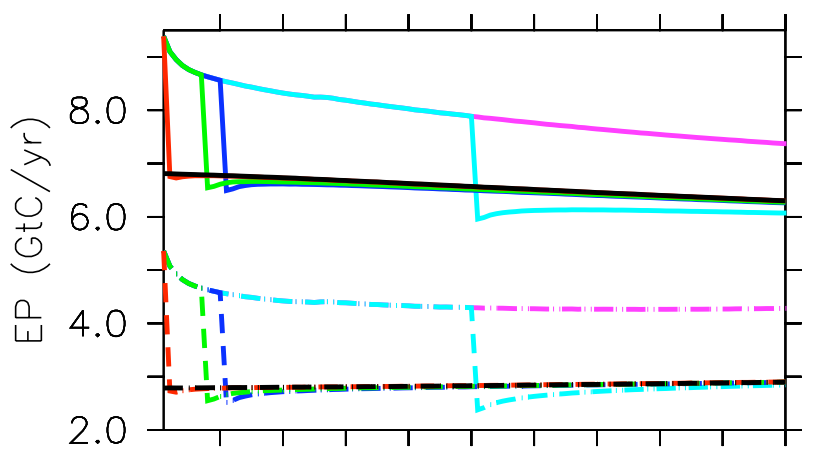

(a) $2020 \quad 2040 \quad 20602080 \quad 2100$

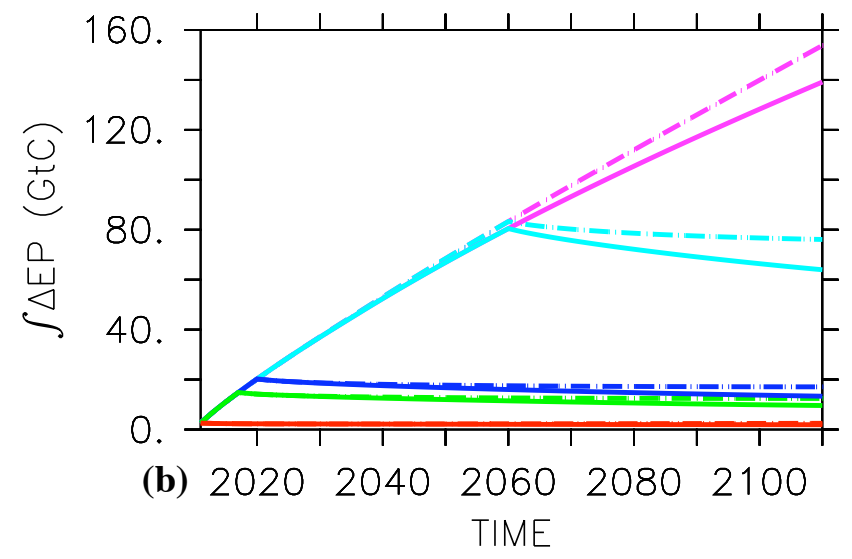

Fig. 5. (a) Simulated annual export production across $z=125 \mathrm{~m}$ south of $30^{\circ} \mathrm{S}$ (dashed lines) and integrated over the global ocean (solid lines). Units are GtC/yr. (b) Cumulative temporal integral of the fertilization-induced change in export production south of $30^{\circ} \mathrm{S}$ (dashed lines) and for the global ocean (solid lines). Units are GtC. Black line in (a) is the control experiment without iron fertilization. Note that simulated export production decreases from $6.8 \mathrm{GtC} / \mathrm{yr}$ in 2010 to $6.3 \mathrm{GtC} / \mathrm{yr}$ in 2100 in response to global warming. Coloured lines refer to the different fertilization experiments, stopping fertilization after 1 year (red), 7 years (green), 10 years (blue), 50 years (cyan) and not at all within the first 100 years (magenta).

to the reduced availability of surface nutrients and the sudden decrease of maximum growth rates once OIF is stopped. Within a few years, upwelling increases surface macronutrient concentrations well above the half-saturation constant for nutrient uptake $\left(0.7 \mathrm{mmol} \mathrm{NO}_{3} \mathrm{~m}^{-3}\right)$, and Southern Ocean export production recovers to levels of the control run (Fig. 5a). Thereafter, Southern Ocean export production stays at pre-OIF levels even though surface nitrate concentrations do not reach those of the control run until the end of the 100-year simulation period considered here. This difference in recovery time scales is due to the fact that macronutrients do not limit export production in the Southern Ocean.

\subsubsection{Remote impacts}

As a result of the OIF-induced trapping of nutrients below the fertilized region, less nutrients are available in the rest of the ocean. Eventually, this leads to reduced biological production and organic matter export outside the fertilized area (Sarmiento and Orr, 1991; Gnanadesikan et al., 2003), which cancels some of the local increase in export production in the fertilized area. By year 2110, cumulative global OIF-induced export production amounts to $139 \mathrm{GtC}$, i.e. about $10 \%$ less than the $154 \mathrm{GtC}$ of cumulative OIF-induced export production simulated in the fertilized region. That is, simulated Southern Ocean iron fertilization leads to a reduction of export production outside the fertilized area. Integrated over the unfertilized area, i.e. north of $30^{\circ} \mathrm{S}$, export production simulated for year 2110 is about $9 \%$ smaller in the OIF run $(3.1 \mathrm{GtC} / \mathrm{yr})$ than in the unfertilized control run $(3.4 \mathrm{GtC} / \mathrm{yr})$.

Once simulated OIF is stopped, export production recovers more slowly outside the fertilization region than inside. This is related to the longer lasting impact of "nutrient robbing" which is in the pipeline in the form of mode waters advected north before reaching the surface layer only after decades to centuries. Global new production and export production therefore remain a few percent lower than those of the control simulation for many decades after OIF has ended (Fig. 5a).

\subsection{Air-sea $\mathrm{CO}_{2}$ flux}

\subsubsection{Local impacts}

The simulated OIF-induced air-sea flux of $\mathrm{CO}_{2}$ into the fertilized area reaches $2 \mathrm{GtC} / \mathrm{yr}$ in the first year of fertilization, then quickly drops off to half of this value in year 10, and levels off at $0.4 \mathrm{GtC} / \mathrm{yr}$ after several decades (Fig. 6a). The associated cumulative air-sea flux of $\mathrm{CO}_{2}$ into the fertilized area amounts to $73 \mathrm{GtC}$ (Fig. 6b), i.e., less than half of the cumulative OIF-induced local export production of $154 \mathrm{GtC}$ (Fig. 5b). That fertilization-induced air-sea $\mathrm{CO}_{2}$ fluxes are considerably smaller than the associated export production has been shown previously (Gnanadesikan et al., 2003; Oschlies, 2009; Sarmiento et al., 2010) and can to a large extent be explained by shallow remineralization, subsequent upwelling, and entrainment of the respired carbon back into the surface mixed layer. The ratio of air-sea $\mathrm{CO}_{2}$ flux to export production has been termed "atmospheric uptake efficiency" (Jin et al., 2008). There is model-based evidence for higher uptake efficiencies when OIF is performed in surface mixed layers shallower than the $50 \mathrm{~m}$ thickness of the top box in our current model (Jin et al., 2008; Sarmiento et al., 2010). It is therefore possible that our model underestimates the fertilization-induced oceanic $\mathrm{CO}_{2}$ uptake. However, the magnitude of this bias and its dependence on the way particulate matter export is described is as yet uncertain and has to be investigated in the future. 


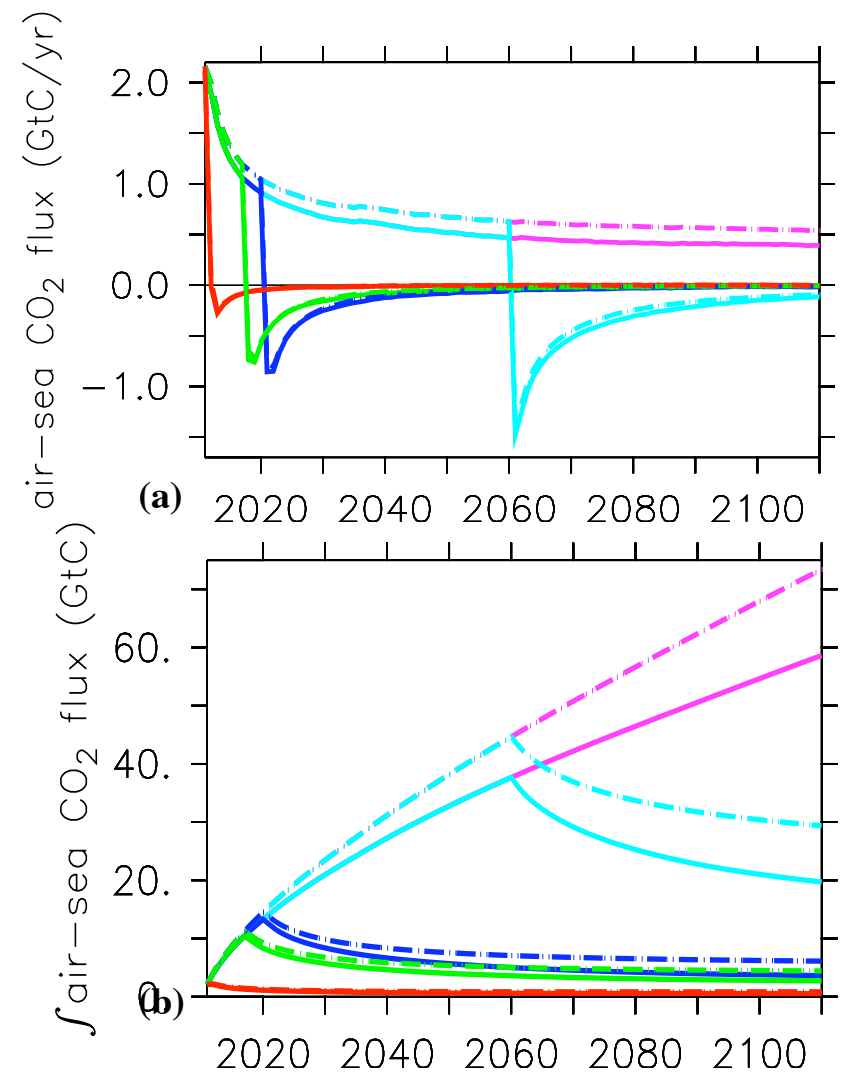

Fig. 6. (a) Simulated fertilization-induced annual air-sea $\mathrm{CO}_{2}$ flux south of $30^{\circ} \mathrm{S}$ (dashed lines) and integrated over the global ocean (solid lines). Units are GtC/yr. (b) Cumulative temporal integral of the fertilization-induced change in air-sea flux of $\mathrm{CO}_{2}$ south of $30^{\circ} \mathrm{S}$ (dashed lines) and for the global ocean (solid lines). Units are $\mathrm{GtC}$. Coloured lines refer to the different fertilization experiments, stopping fertilization after 1 year (red), 7 years (green), 10 years (blue), 50 years (cyan) and not at all within the first 100 years (magenta).

While the cumulative export production declines by only a few percent after stopping fertilization, cumulative Southern Ocean air-sea $\mathrm{CO}_{2}$ flux by year 2110 decreases by almost two thirds (one third) once fertilization is stopped in the 1-, 7- and 10-year (50-year) fertilization experiments (Fig. 6b). Obviously, much of the $\mathrm{CO}_{2}$ initially sequestered in the Southern Ocean is fluxed back to the atmosphere once OIF is stopped. This outgassing from the fertilized area occurs at rates that, for a brief period, may exceed $1 \mathrm{GtC} / \mathrm{yr}$ (Fig. 6a). Once export production becomes limited by iron again, nutrient levels of the upwelled waters as well as associated concentrations of dissolved inorganic carbon cannot be drawn down anymore. In consequence, partial pressure of $\mathrm{CO}_{2}$ in the upwelled surface waters increases and $\mathrm{CO}_{2}$ is fluxed back to the atmosphere. Thus, only part of the $\mathrm{CO}_{2}$ sequestered by temporary Southern Ocean OIF is sequestered on a 100-year time horizon. The return flux of large parts of the initially sequestered carbon to the atmosphere will have to be accounted for many decades after the end of iron fertilization efforts.

\subsubsection{Remote impacts}

The cumulative OIF-induced global air-sea $\mathrm{CO}_{2}$ flux amounts to $59 \mathrm{GtC}$ by the year 2110 of the continuous OIF experiment, which is some $19 \%$ less than the air-sea $\mathrm{CO}_{2}$ flux integrated over the fertilized Southern Ocean. The global OIF-induced oceanic $\mathrm{CO}_{2}$ uptake decreases from $2.1 \mathrm{GtC} / \mathrm{yr}$ in the first fertilization year to $0.9 \mathrm{GtC} / \mathrm{yr}$ in year 10 and $0.4 \mathrm{GtC} / \mathrm{yr}$ after year 55 of the continuous fertilization experiment. OIF induces a net back flux of $\mathrm{CO}_{2}$ from the unfertilized ocean regions to the atmosphere, which reaches maximum values of about $0.16 \mathrm{GtC} / \mathrm{yr}$ in year 70 and falls off to $0.15 \mathrm{GtC} / \mathrm{yr}$ in year 100 of the continuous fertilization run. This back flux is a consequence of the success of the simulated OIF, i.e., of reduced atmospheric $p \mathrm{CO}_{2}$ which reduces the air-sea $p \mathrm{CO}_{2}$ pressure gradient everywhere (Oschlies, 2009).

\section{5 $\quad \mathrm{N}_{2} \mathrm{O}$ emissions}

\subsubsection{Local impacts}

Among the possible side effects of the intended carbon sequestration by ocean iron fertilization is the enhanced emission of the greenhouse gas $\mathrm{N}_{2} \mathrm{O}$ from the ocean to the atmosphere. Nitrous oxide has a global warming potential about 300 times as large as carbon dioxide (on a per-molecule basis and for a 100-year time horizon; Ramaswamy et al., 2001) and has been proposed to offset part of the radiative benefit that may result from OIF-induced $\mathrm{CO}_{2}$ sequestration (Jin and Gruber, 2003). The gas is produced in the ocean mainly via two pathways. The first pathway is nitrification, which describes the oxidation of remineralized ammonium to nitrate and where about 1 ammonium molecule in 1000 is estimated to be converted to $\mathrm{N}_{2} \mathrm{O}$ (Cohen and Gordon, 1979). The second pathway is related to organic matter remineralization at low oxygen concentrations where a combination of nitrification and denitrification appears to result in $\mathrm{N}_{2} \mathrm{O}$ yields more than an order of magnitude higher than for the aerobic nitrification route. For both pathways, yields generally increase with decreasing oxygen concentrations, until $\mathrm{N}_{2} \mathrm{O}$ is efficiently consumed at oxygen concentrations lower than a very few $\mu \mathrm{M}$ (Bange et al., 2005).

There are still substantial uncertainties in our understanding of the detailed controls on the $\mathrm{N}_{2} \mathrm{O}$ yields. Two different parameterizations of $\mathrm{N}_{2} \mathrm{O}$ production as a function of organic matter remineralization and oxygen concentrations are employed here: For the parameterization by Suntharalingam et al. (2000), our unfertilized control run simulates oceanic $\mathrm{N}_{2} \mathrm{O}$ emissions of about $3.5 \mathrm{TgN} / \mathrm{yr}$, and it simulates 4.6 TgN/yr for the parameterization by Nevison et al. (2003). Both estimates are well within the $3.8 \pm 2.0 \mathrm{TgN} / \mathrm{yr}$ range of the most recent IPCC report (Denman et al., 2007).

OIF-induced enhancements of carbon export and subsequent remineralization lead to enhanced production of $\mathrm{N}_{2} \mathrm{O}$ 


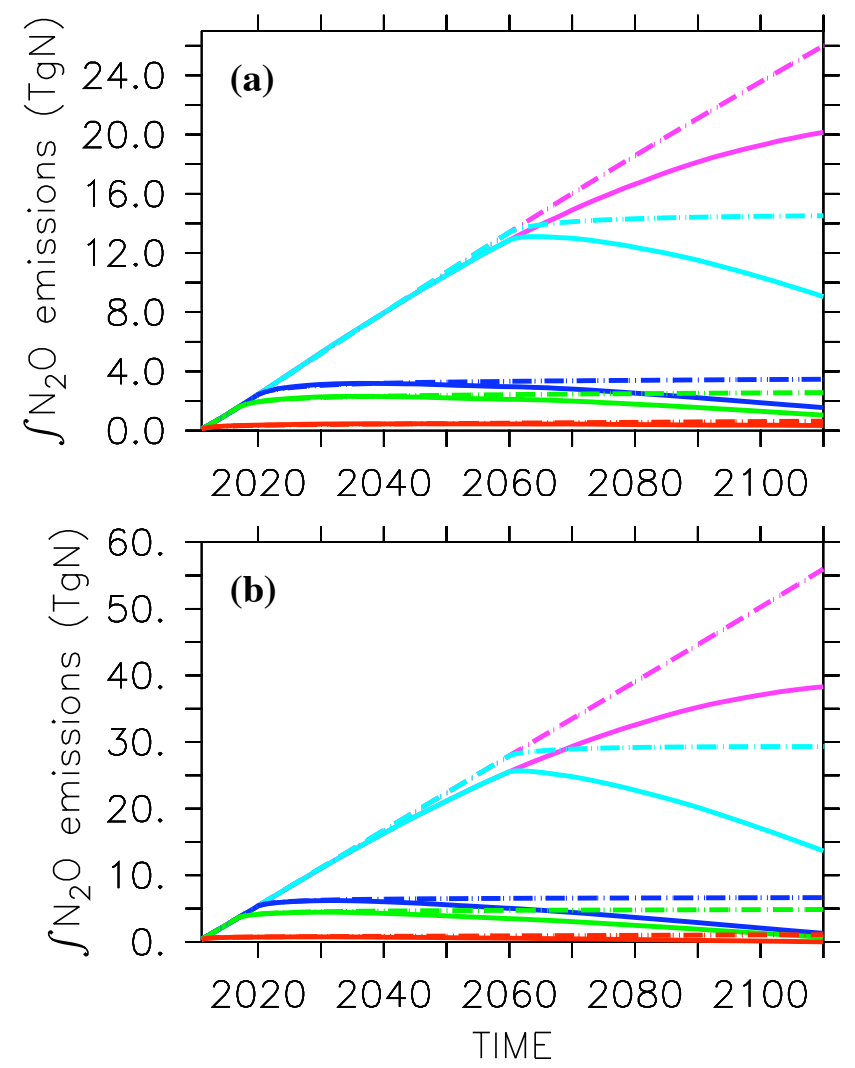

Fig. 7. Cumulative temporal integral of the fertilization-induced sea-air flux of $\mathrm{N}_{2} \mathrm{O}$ using the parameterizations of (a) Suntharalingam et al. (2000), and (b) Nevison et al. (2003) for oceanic $\mathrm{N}_{2} \mathrm{O}$ production (see text). Dashed lines refer to fertilization-induced $\mathrm{N}_{2} \mathrm{O}$ emissions in the fertilization region, solid lines refer to global fertilization-induced emissions. Units are TgN. Colour code as in Fig. 4.

and subsequently to enhanced oceanic emissions from the fertilized area. For the Suntharalingam et al. (2000) parameterization, cumulative Southern Ocean OIF-induced $\mathrm{N}_{2} \mathrm{O}$ emissions amount to some $26 \mathrm{TgN}$ for 100 years of continuous OIF. For the Nevison et al. (2003) parameterization, the figure is about twice as high and reaches $56 \mathrm{TgN}$ (Fig. 7). Because Southern Ocean oxygen concentrations remain well above $100 \mathrm{mmol} \mathrm{m}^{-3}$, the low-oxygen pathway of $\mathrm{N}_{2} \mathrm{O}$ production does not play any significant role in this region. Instead, local OIF-induced $\mathrm{N}_{2} \mathrm{O}$ production is directly linked to enhanced nitrification and remineralization of exported organic matter in our model. Southern Ocean OIF-induced $\mathrm{N}_{2} \mathrm{O}$ production therefore stops immediately once OIF is stopped and carbon export and associated remineralization drop back to the rates of the control run (horizontal dashed lines in Fig. 7).

\subsubsection{Remote impacts}

During the first few decades, simulated global OIF-induced $\mathrm{N}_{2} \mathrm{O}$ emissions are identical to the regional $\mathrm{N}_{2} \mathrm{O}$ emissions from the fertilized area. It is only after a 2 to 3 decades that global OIF-induced $\mathrm{N}_{2} \mathrm{O}$ emissions fall below those of the fertilized region (Fig. 7). This is about the time when the mode waters formed in the fertilization area reach the tropical oxygen minimum zones and simulated suboxic regions start to shrink (Fig. 4b). This leads to a reduction in $\mathrm{N}_{2} \mathrm{O}$ production via the low-oxygen pathway. By year 2110, the reduction in tropical $\mathrm{N}_{2} \mathrm{O}$ production almost cancels the increase in Southern Ocean $\mathrm{N}_{2} \mathrm{O}$ production, and cumulative global OIF-induced $\mathrm{N}_{2} \mathrm{O}$ do not increase further in the continuous OIF experiment, reaching $20 \mathrm{TgN}(38 \mathrm{TgN})$ for the Suntharalingam et al. (2000) (Nevison et al., 2003) parameterizations, respectively, i.e., $6 \mathrm{TgN}(18 \mathrm{TgN})$ less than the local emissions from the fertilized region.

Given the global warming potential of about 300 times that of $\mathrm{CO}_{2}$, OIF-induced $\mathrm{N}_{2} \mathrm{O}$ emissions of $20 \mathrm{TgN}(38 \mathrm{TgN})$ would offset about $2.7 \mathrm{GtC}(5.0 \mathrm{GtC})$ of the OIF-induced carbon sequestration on a 100 -year timescale for the Suntharalingam et al. (2000) and Nevison et al. (2003) parameterizations, respectively. This corresponds to an offset of $5 \%$ and $9 \%$ for the two estimates of global $\mathrm{N}_{2} \mathrm{O}$ emissions. These estimates are very similar to the $6 \%$ to $12 \%$ range obtained by Law and Ling (2001) from measurements of elevated pycnocline $\mathrm{N}_{2} \mathrm{O}$ concentrations during the Southern Ocean Iron Enrichment Experiment SOIREE). Measurements during the European Iron Fertilization Experiment (EIFEX), however, revealed no significant increase in $\mathrm{N}_{2} \mathrm{O}$ concentrations in the fertilized water column (Walter et al., 2005).

While simulated OIF-induced Southern Ocean $\mathrm{N}_{2} \mathrm{O}$ emissions almost instantaneously drop to zero when OIF is stopped, reduced $\mathrm{N}_{2} \mathrm{O}$ production via the tropical lowoxygen pathway continues for many decades. This follows the decline in suboxic volumes long after OIF is stopped (Fig. 4b), which in turn is caused by lower nutrient concentrations in the "mode water pipeline" downstream of the fertilized area.

\subsection{Methane emissions}

Methane $\left(\mathrm{CH}_{4}\right)$ is a greenhouse gas with a radiative forcing strength and a global warming potential about 20 times that of $\mathrm{CO}_{2}$ (on a per molecule basis and for a 100-year horizon; Ramaswamy et al., 2001). Early estimates of oceanic $\mathrm{CH}_{4}$ emissions amounted to 10-20 Tg/yr (Bange et al., 1994). These were used in the 1990 to 2007 IPCC reports, but have been revised downward to $0.4 \pm 0.2 \mathrm{Tg} / \mathrm{yr}$ (Bates et al., 1996) and 0.6-1.2 Tg/yr more recently (Rhee et al., 2009).

Methane producing bacteria are thought to require strictly anoxic conditions which, in the open ocean, only exists in form of microhabitats associated with particulate organic material (Karl and Tilbrook, 1994). Recently, aerobic 


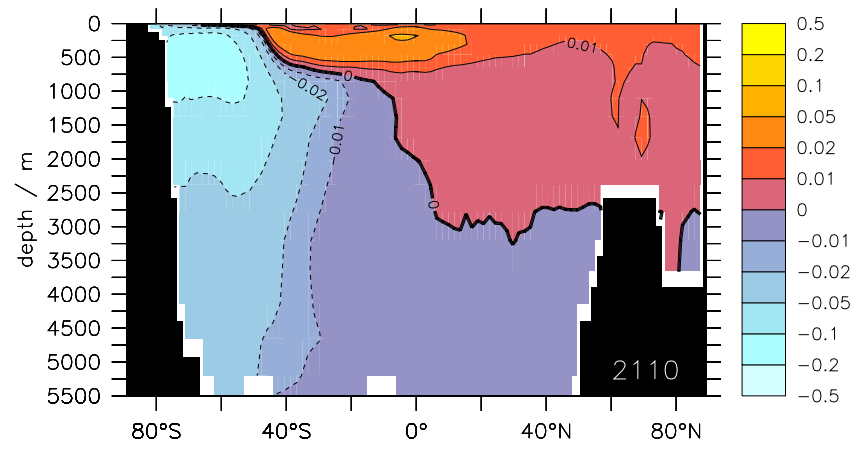

Fig. 8. Zonally averaged OIF-induced change in $\mathrm{pH}$ in year 2110 of the continuous fertilization experiment.

degradation of an organic, phosphorus-containing compound was identified as a significant mechanism for $\mathrm{CH}_{4}$ production in phosphate-depleted surface waters (Karl et al., 2008). As simulated Southern Ocean iron fertilization does not lead to anoxic conditions or to a large-scale depletion of surface macronutrients (Fig. 2), we assume that OIF-induced changes in $\mathrm{CH}_{4}$ production are approximately proportional to the production of organic particles that may host anoxic microhabitats for the methane producing bacteria. With a simulated OIF-induced enhancement of global export production by some 15-20\% (Fig. 5a), we can then estimate a similar increase in oceanic $\mathrm{CH}_{4}$ emissions, i.e. less than $0.2 \mathrm{Tg} / \mathrm{yr}$. Measurements of dissolved $\mathrm{CH}_{4}$ during the Southern Ocean Iron Enrichment Experiment (SOFeX) revealed an even smaller increase by less than $1 \%$ (Wingenter et al., 2004). With the global warming potential of methane being about 20 times as high as that of $\mathrm{CO}_{2}$, even a $20 \%$ enhancement of $\mathrm{CH}_{4}$ emissions could offset a carbon sequestration of some $4 \mathrm{TgC} / \mathrm{yr}$, i.e. less than $1 \%$ of the OIF-induced carbon sequestration simulated by our model. Given this small estimated impact and the difficulties to parameterize the involved anoxic microhabitats, we do not attempt to simulate a more detailed picture of OIF-enhanced marine methane production and in the following disregard potential OIF-induced changes in $\mathrm{CH}_{4}$ emissions.

\subsection{Ocean acidification}

To the extent that OIF sequesters additional $\mathrm{CO}_{2}$ in the ocean, it will also amplify ocean acidification (Denman, 2008). This is most pronounced in areas where the sequestered $\mathrm{CO}_{2}$ is stored. In our model, OIF-induced acidification is largest in the upper few hundred meters of the Southern Ocean, where most of the exported carbon remineralizes and thereby releases $\mathrm{CO}_{2}$. In this depth range, $\mathrm{pH}$ drops by another 0.15 units compared to the control run in year 2110 (Fig. 8) and the saturation state for calcium carbonate, $\Omega_{\mathrm{CaCO}_{3}}$ drops by up to 0.4 units. The change in $\mathrm{pH}$ generally follows the OIF-induced change in DIC (Fig. 3b), although changes in nutrient concentrations (and, to a minor

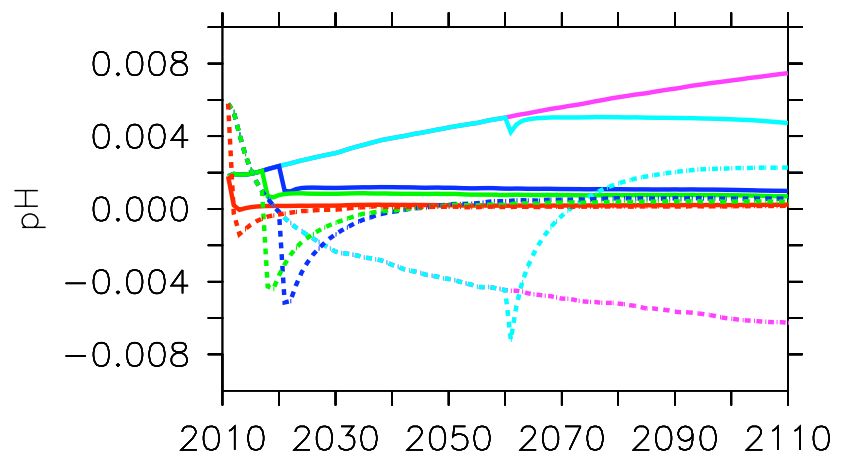

Fig. 9. Simulated evolution of OIF-induced changes in surface $\mathrm{pH}$ (averaged over 0-125 $\mathrm{m}$ depth). Dashed lines refer to $\mathrm{pH}$ changes averaged over the fertilized area south of $30^{\circ} \mathrm{S}$, solid lines refer to the globally averaged $\mathrm{pH}$ changes.

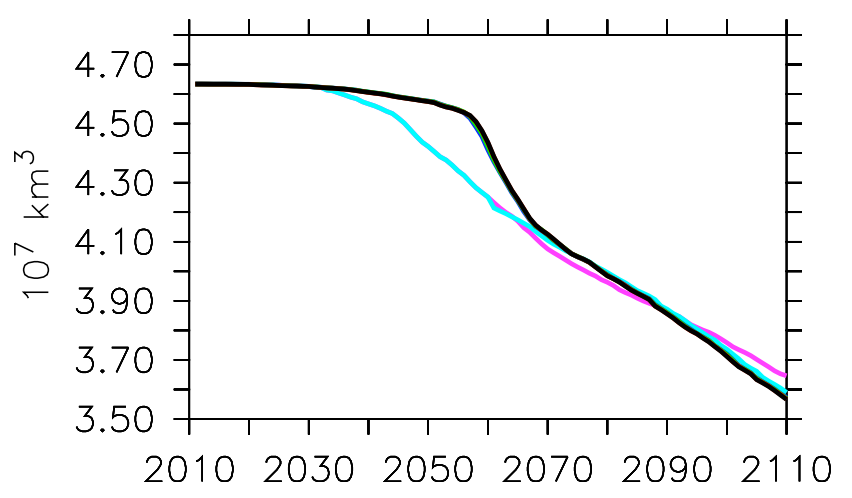

Fig. 10. Temporal evolution of the simulated volume of surface $(0-$ $100 \mathrm{~m}$ ) waters with arragonate saturation state $\Omega_{\mathrm{Ar}}>1$. The black line refers to the unfertilized control experiments, the OIF experiments are referred to by the same color code as in Fig. 4.

extent, simulated changes in calcium carbonate production and dissolution) have some impact on alkalinity and hence $\mathrm{pH}$. Simulated surface $\mathrm{pH}$ decreases in the fertilized region by $0.006 \mathrm{pH}$ units (Fig. 9), whereas it increases almost everywhere outside the fertilized area. The OIF-induced globally averaged increase in surface $\mathrm{pH}$ by some $0.007 \mathrm{pH}$ units slightly counteracts the much larger $\mathrm{pH}$ decrease by $0.34 \mathrm{pH}$ units simulated by the unfertilized control experiment under the SRES A2 scenario by year 2110 .

Acidification induced by Southern Ocean large-scale iron fertilization is thus expected to be a specific problem in Southern Ocean near-surface waters, which are projected to become persistently undersaturated with respect to aragonite by mid-century already without OIF (Orr et al., 2005). This development is also simulated by our model, which reveals that by 2110 about $20 \%$ of the ocean volume is undersaturated with respect to aragonite. Simulated Southern Ocean OIF leads to an acceleration of this process by a few decades (Fig. 10). However, once the Southern Ocean is undersaturated, the global volume of undersaturated waters increases 
at a slower rate in the continuous OIF experiment that simulates slightly higher saturation states than the control run outside the fertilized region.

\subsection{Other impacts}

As OIF is an intended manipulation of marine ecosystems, it will impact ecology at least locally. Species composition is likely to change and may affect the production or consumption of any single biotically processed chemical compound. This includes the possible stimulation of the production of dimethylsulfide (DMS), which may reinforce possible climate-mitigation effects of OIF by generating more cloud condensation nuclei and eventually increasing the Earth's albedo (Law, 2008). Other possible effects are changes in the occurrence of toxic algal blooms (Trick et al., 2010), which may also be felt up higher up in the food chain. Ocean acidification may affect the availability of iron to phytoplankton (Shi et al., 2010) and thereby influence the mitigation potential of iron fertilization. None of these effects is included in our model. While the neglect of changes in DMS production could be considered as conservative accounting approach, the neglect of ecological consequences might be more critical. More information about the impact of OIFinduced ecological changes is needed (Buesseler et al., 2008) and can possibly be obtained from the ongoing natural iron fertilization such as associated with the Kerguelen Plateau and Crozet Islands.

\section{Discussion}

Given the expected non-local and time-lagged impacts of simulated Southern Ocean iron fertilization on the air-sea fluxes of $\mathrm{CO}_{2}$ and other greenhouse gases, verification and accounting of OIF-induced carbon sequestration would be a particular challenge (Cullen and Boyd, 2008). Non-local and time-lagged impacts are also an issue for terrestrial carbon sequestration, e.g. by forestation, where these difficulties are generally formulated in terms of leakage and permanence. The two terms apply to compensation back fluxes of $\mathrm{CO}_{2}$ and other greenhouse gases outside regional and temporal boundaries of the sequestration project. In the moving ocean, a separation into spatial and temporal side effects may be less meaningful as increasing time lags are often associated with increasing space lags. Still, some separation of OIF side effects into regional and temporal lags may be illustrative and will be applied here.

For the large-scale Southern Ocean iron fertilization investigated here, there is a compensating back flux from the ocean to the atmosphere outside the fertilization region (Table 1). This back flux is caused primarily by the reduction of the atmospheric $\mathrm{CO}_{2}$, which makes the air-sea gradient of $\mathrm{CO}_{2}$ partial pressures more negative in the unfertilized areas and thus favors outgassing of $\mathrm{CO}_{2}$. The more successful OIF is in sequestering atmospheric $\mathrm{CO}_{2}$, the larger will this effect be. We note, that such a back flux from the ocean to the atmosphere will also occur when $\mathrm{CO}_{2}$ is sequestered on land, e.g., by forestation.

In the case of our simulation of continuous large-scale Southern Ocean iron fertilization, this back flux cancels about $19 \%$ of the OIF-induced air-sea $\mathrm{CO}_{2}$ flux in the fertilized region. Because outgassing outside the fertilized area continues for many decades after the end of simulated OIF (Fig. 6), this cancelation is higher in the runs with shorter OIF and reaches $38 \%$ in the run where OIF is terminated after 7 years. Even higher compensatory back fluxes of more than $40 \%$ were found for simulated short-term iron fertilization in the tropical Pacific (Gnanadesikan et al., 2003).

Other leakage effects are due to OIF-induced emissions of greenhouse gases other than $\mathrm{CO}_{2}$. Our model results predict that OIF-induced enhancement of $\mathrm{N}_{2} \mathrm{O}$ emissions, which occur primarily over the fertilized area, will offset between 5\% and $9 \%$ of the sequestered $\mathrm{CO}_{2}$. This is in close agreement with results of the earlier study by Jin and Gruber (2003). Simulated $\mathrm{N}_{2} \mathrm{O}$ emissions eventually decrease because of the reduction in tropical oxygen minimum zones resulting, in our model, from large-scale Southern Ocean iron fertilization.

Recent studies suggest different carbon sequestration efficiencies of surface nutrient utilization to the south and to the north of the "biogeochemical divide" (Marinov et al., 2006), approximately marked by the surface density contour of $\sigma_{0}=$ 27.3 and separating regions of Antarctic Bottom Water formation to the south of the divide from regions of Antarctic Intermediate Water and Subantarctic Mode Water formation to the north. In order to test for possible different impacts of OIF performed north and south of the biogeochemical divide, a number of sensitivity experiments were performed with the area of simulated OIF restricted to Southern Ocean surface waters denser than $\sigma_{0}=26.4,26.8,27.2$, and 27.4, respectively (Table 2). OIF in waters denser than $\sigma_{0}=27.6$ was simulated as well, but will not be analyzed further as this surface density class disappears in the global warming simulation after year 2060. The model results agree with those of earlier studies (Sarmiento et al., 2010) in that the ratio of OIF-induced oceanic $\mathrm{CO}_{2}$ uptake to OIF-induced export production increases when more southerly waters are fertilized, namely from a cumulative atmospheric uptake efficiency of 0.42 for OIF everywhere south of $30^{\circ} \mathrm{S}$ to a value of 0.51 for OIF only applied to surface waters denser than $\sigma_{0}=27.4$ (Fig. 11). This sequestration efficiency is much higher than found, for example, in earlier "year-round" nutrient depletion simulations (Sarmiento and Orr, 1991) that generated high export fluxes even during winter, when instantaneous upward mixing of exported and respired carbon within the deep mixed layers did not allow for the development of appreciable vertical gradients in inorganic carbon and nutrient concentrations. 
Table 1. Model results.

\begin{tabular}{|c|c|c|c|c|c|}
\hline & $1-\mathrm{yr}$ OIF & $7-\mathrm{yr}$ OIF & $10-y r$ OIF & $50-\mathrm{yr}$ OIF & $100-y r$ OIF \\
\hline \multicolumn{6}{|c|}{ Cumulative OIF-induced export production, year 2110 (GtC) } \\
\hline fertilized area & 2.62 & 12.6 & 17.2 & 76.1 & 154 \\
\hline outside fertilized area & -0.24 & -2.4 & -3.4 & -12.0 & -14.6 \\
\hline global & 2.37 & 10.2 & 13.8 & 64.2 & 139 \\
\hline \multicolumn{6}{|c|}{ Cumulative OIF-induced air-sea $\mathrm{CO}_{2}$ flux, year $2110(\mathrm{GtC})$} \\
\hline fertilized area & 0.83 & 4.42 & 6.11 & 29.4 & 73.4 \\
\hline outside fertilized area & -0.31 & -1.70 & -2.50 & -9.7 & -14.8 \\
\hline global & 0.53 & 2.73 & 3.61 & 19.7 & 58.6 \\
\hline \multicolumn{6}{|c|}{ Ratio of cumul. OIF-induced air-sea flux to cumul. export production, year 2110} \\
\hline global & 0.22 & 0.27 & 0.26 & 0.31 & 0.42 \\
\hline \multicolumn{6}{|c|}{ OIF-induced terrestrial C loss, year $2110(\mathrm{GtC})$} \\
\hline global & -0.40 & 0.28 & -0.008 & 1.9 & 4.5 \\
\hline \multicolumn{6}{|c|}{ OIF-induced atmospheric $\mathrm{CO}_{2}$ decline, year $2110(\mathrm{GtC})$} \\
\hline global & 0.93 & 2.45 & 3.62 & 17.9 & 54.2 \\
\hline \multicolumn{6}{|c|}{ Ratio of OIF-induced atmospheric $\mathrm{CO}_{2}$ decline to oceanic $\mathrm{CO}_{2}$ uptake, year 2110} \\
\hline global & 1.78 & 0.90 & 1.003 & 0.91 & 0.92 \\
\hline \multicolumn{6}{|c|}{ OIF-induced decline in atm. $p \mathrm{CO}_{2}$ and surface temperature, year 2110} \\
\hline$\Delta p \mathrm{CO}_{2}(\mu \mathrm{atm})$ & -0.43 & -1.17 & -1.73 & -8.56 & -25.9 \\
\hline$\triangle \mathrm{SAT}\left({ }^{\circ} \mathrm{C}\right)$ & -0.011 & -0.0049 & -0.013 & -0.039 & -0.096 \\
\hline
\end{tabular}

All experiments use the SRES A2 emission scenario and start Ocean Iron Fertilization (OIF) everywhere south of $30^{\circ} \mathrm{S}$ in year 2011 . Export production is computed as all simulated organic carbon export across $z=125 \mathrm{~m}$.

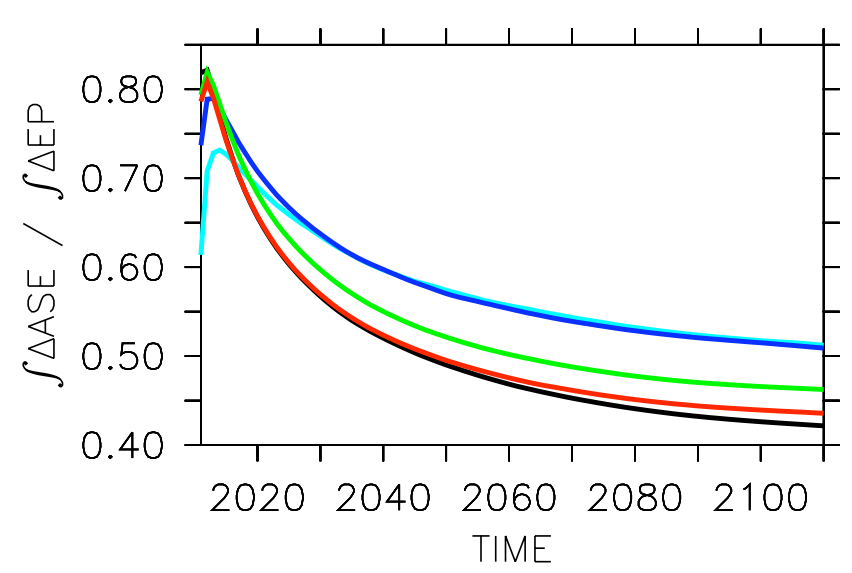

Fig. 11. Ratio of cumulative global OIF-induced air-sea $\mathrm{CO}_{2}$ flux to cumulative global OIF-induced export production for simulated continuous OIF applied to surface waters everywhere south of $30^{\circ} \mathrm{S}$ (black), surface waters denser than $\sigma_{0}=26.4$ (red), denser than $\sigma_{0}=26.8$ (green), $\sigma_{0}=27.2$ (blue) and $\sigma_{0}=27.4$ (cyan).
Continuous OIF applied to surface waters denser than $\sigma_{0}=27.4$ can, in our simulation, sequester some $12.6 \mathrm{GtC}$ by the year 2110. Potential side effects such as the offset in global warming potential by OIF-related emissions of $\mathrm{N}_{2} \mathrm{O}$ are somewhat smaller when only waters south of the biogeochemical divide are fertilized. For fertilization restricted to the densest waters, $\mathrm{N}_{2} \mathrm{O}$ emissions simulated by the Nevison et al. (2003) parameterization offset about $3.1 \%$ of the atmospheric $\mathrm{CO}_{2}$ sequestered, whereas $8.7 \%$ are offset for fertilization everywhere south of $30^{\circ} \mathrm{S}$ (Table 2 ). Interestingly, the reduction in the extent of suboxic waters is almost exactly proportional to the sequestered atmospheric $\mathrm{CO}_{2}$ with $0.44 \%$ reduction in suboxic volume per gigatonne carbon sequestered by year 2110 , no matter whether simulated OIF is applied north or south of the biogeochemical divide. Closer inspection reveals that even for fertilization restricted to densities larger than $\sigma_{0}=27.4$, part of the fertilized waters move northward within the shallow summer mixed layers and are transformed into lighter Subantarctic mode waters. Upon subduction they export their OIFinduced nitrate deficit northward, where reduced new production and export production eventually lead to a reduction in oxygen consumption in the tropical oceans even for OIF 
Table 2. Sensitivity to fertilized surface area.

\begin{tabular}{|c|c|c|c|c|c|}
\hline & $<30^{\circ} \mathrm{S}$ & $\sigma_{0}>26.4$ & $\sigma_{0}>26.8$ & $\sigma_{0}>27.2$ & $\sigma_{0}>27.4$ \\
\hline \multicolumn{6}{|c|}{ Cumulative OIF-induced export production, year 2110 (GtC) } \\
\hline south of $30^{\circ} \mathrm{S}$ & 154 & 129 & 105 & 55.6 & 25.3 \\
\hline north of $30^{\circ} \mathrm{S}$ & -14.6 & -9.3 & -6.4 & -2.3 & -0.75 \\
\hline global & 139 & 120 & 98.3 & 53.3 & 24.6 \\
\hline \multicolumn{6}{|c|}{ Cumulative OIF-induced air-sea $\mathrm{CO}_{2}$ flux, year $2110(\mathrm{GtC})$} \\
\hline south of $30^{\circ} \mathrm{S}$ & 73.4 & 61.6 & 52.9 & 31.0 & 14.3 \\
\hline north of $30^{\circ} \mathrm{S}$ & -14.8 & -9.4 & -7.5 & -3.9 & -1.7 \\
\hline global & 58.6 & 52.2 & 45.4 & 27.1 & 12.6 \\
\hline \multicolumn{6}{|c|}{ Ratio of cumul. OIF-induced air-sea flux to cumul. export production, year 2110} \\
\hline global & 0.42 & 0.44 & 0.46 & 0.51 & 0.51 \\
\hline \multicolumn{6}{|c|}{ OIF-induced terrestrial C loss, year $2110(\mathrm{GtC})$} \\
\hline global & 4.5 & 3.9 & 3.6 & 2.0 & 1.1 \\
\hline \multicolumn{6}{|c|}{ OIF-induced atmospheric $\mathrm{CO}_{2}$ decline, year $2110(\mathrm{GtC})$} \\
\hline global & 54.2 & 48.3 & 41.8 & 25.1 & 11.5 \\
\hline \multicolumn{6}{|c|}{ Ratio of OIF-induced atmosph[2mm]eric $\mathrm{CO}_{2}$ decline to oceanic $\mathrm{CO}_{2}$ uptake, year 2110} \\
\hline global & 0.92 & 0.93 & 0.92 & 0.93 & 0.91 \\
\hline \multicolumn{6}{|c|}{ OIF-induced change in suboxic volume, year $2110(\%)$} \\
\hline global & -25.9 & -23.0 & -20.0 & -12.0 & -5.4 \\
\hline \multicolumn{6}{|c|}{ Offset by OIF-related $\mathrm{N}_{2} \mathrm{O}$ emissions (\%) } \\
\hline global & 8.7 & 7.1 & 5.3 & 3.6 & 3.1 \\
\hline
\end{tabular}

All experiments use the SRES A2 emission scenario and apply Ocean Iron Fertilization (OIF) for 100 years beginning in year 2011. Export production is computed as all simulated organic carbon export across $z=125 \mathrm{~m}$. $\mathrm{N}_{2} \mathrm{O}$ production is simulated using the Nevison et al. (2003) parameterization.

south of the biogeochemical divide. Such a northward export of a fertilization-induced nutrient deficit was effectively suppressed by restoring surface nutrients to observed concentrations everywhere outside the fertilization area in the model of Marinov et al. (2006).

An interesting finding of our Earth System model simulations is that even when the back flux of $\mathrm{CO}_{2}$ from the unfertilized areas is accounted for, the OIF-induced drawdown in atmospheric $\mathrm{CO}_{2}$ is, by year 2110 , about $8 \%$ smaller than the cumulative global air-sea flux (Fig. 12). The reason for this discrepancy is the terrestrial carbon pool that responds to lowered atmospheric $\mathrm{CO}_{2}$ and associated climate change with respect to the unfertilized control simulation. The vegetation model used in the UVic Earth System model has sensitivities to changes in atmospheric $\mathrm{CO}_{2}$ and temperature in the middle ranges of the Coupled Climate-Carbon Cycle Model Intercomparison Project ( $\mathrm{C}^{4} \mathrm{MIP}$ ) models (Friedlingstein et al., 2006). In general, elevated atmospheric $\mathrm{CO}_{2}$ tends to fertilize the terrestrial vegetation, whereas warming leads to enhanced carbon losses by respiration. For the OIF-induced changes in atmospheric $\mathrm{CO}_{2}$ and surface air temperature (Ta- ble 1), the OIF-induced reduction in the $\mathrm{CO}_{2}$ fertilization effect is about 3 times as large as the reduction in respiratory carbon losses at lower temperatures. As a result, the terrestrial carbon stock of the continuous OIF-experiment is about $4.5 \mathrm{GtC}$ smaller than in the unfertilized control experiment in year 2110 (Table 1). This indicates that of the total carbon sequestered in the ocean, more than $90 \%$ come from the atmosphere and less than $10 \%$ are derived from the terrestrial biosphere. Given the large range of climate sensitivities and $\mathrm{CO}_{2}$ sensitivities of current vegetation models, we estimated the OIF-induced change in terrestrial carbon storage by assuming linearly independent sensitivities with respect to the OIF-induced changes in atmospheric temperature and $\mathrm{CO}_{2}$. For 10 out of the $12 \mathrm{C}^{4} \mathrm{MIP}$ model sensitivities given by Friedlingstein et al. (2006), the estimated OIF-induced terrestrial carbon loss lies within $\pm 30 \%$ of our model result, whereas the two extreme models predict a 3 times higher and 15 times lower terrestrial carbon loss compared to our model in response to Southern Ocean iron fertilization. Sensitivity experiments started from pre-industrial conditions and neglecting anthropogenic $\mathrm{CO}_{2}$ emissions revealed a 


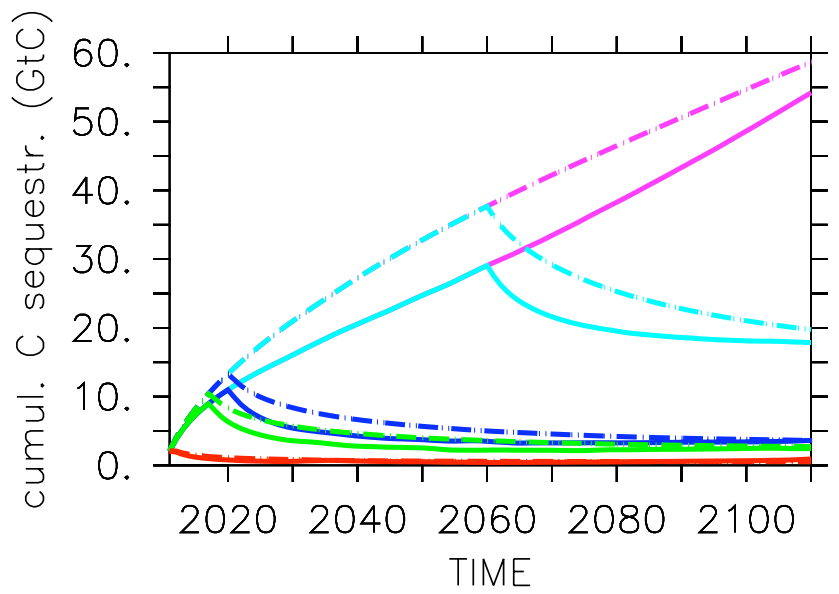

Fig. 12. Solid lines: Cumulative temporal integral of the fertilization-induced reduction in atmospheric $\mathrm{CO}_{2}$. Dashed lines: Cumulative temporal integral of the fertilization-induced change in global air-sea flux of $\mathrm{CO}_{2}$ (same as solid lines in Fig. 6b). Units are GtC. Colour code as in Fig. 4.

much smaller ( $\sim$ factor 2$)$ change in atmospheric $p \mathrm{CO}_{2}$ upon Southern Ocean OIF. This can be attributed to approximately equal parts by the change in the carbonate buffering capacity, which leads to a larger change in $p \mathrm{CO}_{2}$ per DIC drawdown at higher $p \mathrm{CO}_{2}$, and the higher sensitivity of the modeled terrestrial carbon pool at pre-industrial $p \mathrm{CO}_{2}$.

The sensitivities of the terrestrial biosphere to OIFinduced changes in atmospheric $\mathrm{CO}_{2}$ and surface temperature imply that a small part of the $\mathrm{CO}_{2}$ that enters the ocean in response to iron fertilization would be sequestered from the land and not from the atmosphere. In a system of interacting carbon reservoirs this is to be expected. Similarly, forestation sequesters some carbon that eventually derives from the ocean rather than from the atmosphere. Along the same lines, any carbon initially emitted to the atmosphere by anthropogenic activities is also partitioned among atmosphere, ocean, and land biosphere. Because of the different sensitivities of the different carbon pools to climate and $\mathrm{CO}_{2}$, measuring sequestration in individual carbon pools may give results that are not equivalent to canceled emissions.

To estimate the size of $\mathrm{CO}_{2}$ emissions offset by OIF, we performed a series of simulations without OIF, but with emissions reduced by an amount proportional to the carbon sequestered in the above-mentioned OIF experiments. We first reduced $\mathrm{CO}_{2}$ emissions to the atmosphere in a model run with no OIF by an amount of $58.6 \mathrm{GtC}$, i.e. equivalent of the global OIF-induced air-sea flux of $\mathrm{CO}_{2}$ of the 100 -yr continuous fertilization run (Table 1), and distributed in time identical to the temporal evolution of the air-sea $\mathrm{CO}_{2}$ fluxes of the fertilization run (Fig. 6a). It turns out that the $58.6 \mathrm{GtC}$ reduction in atmospheric $\mathrm{CO}_{2}$ emissions yields a reduction of atmospheric $\mathrm{CO}_{2}$ by $46.2 \mathrm{GtC}$ by year 2110 (dashed black line in Fig. 13). This is substantially smaller than the at-

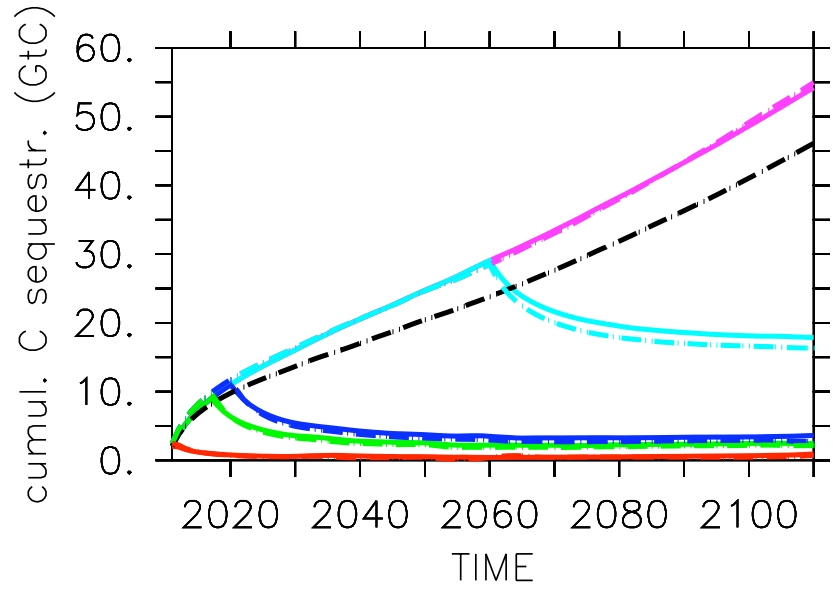

Fig. 13. Solid lines: Cumulative temporal integral of the fertilization-induced reduction in atmospheric $\mathrm{CO}_{2}$ for the different OIF runs. The dashed black line is for emission reductions 1.0 times the air-sea $\mathrm{CO}_{2}$ flux of the continuous iron fertilization run. Dashed colored lines: Cumulative temporal integral of the reduction in atmospheric $\mathrm{CO}_{2}$ achieved by emission reduction 1.2 times the global air-sea $\mathrm{CO}_{2}$ flux of the respective OIF run. Units are GtC. Colour code as in Fig. 4.

mospheric $\mathrm{CO}_{2}$ reduction of $54.2 \mathrm{GtC}$ simulated by the OIF run. The reason for this discrepancy is the sea-air $\mathrm{CO}_{2}$ back flux simulated in response to lowered atmospheric $\mathrm{CO}_{2}$ partial pressure. With simulated emission cuts $20 \%$ higher than the inferred OIF-induced global air-sea fluxes of the respective OIF runs, atmospheric $\mathrm{CO}_{2}$ concentrations simulated by the unfertilized emission-cut runs closely agree with those of the respective OIF experiments (Fig. 13). That is, each ton carbon sequestered in the ocean is, in our model and on a 100 year timescale, equivalent to an emission cut of about 1.2 tons of carbon.

\section{Conclusions}

With the exploitation of fossil fuels and associated emission of $\mathrm{CO}_{2}$ mankind has substantially increased the risk of dangerous climate change. Dealing with this risk in the interest of maximizing a "common good" has to include weighing the risks of using, or not using, climate engineering options. Reiterating the results of earlier studies, our model study indicates that any assessment of the efficacy of OIF must be global in order to account for the downstream effects. Here, we have limited our analysis to the 100 -year time scale adopted by the IPCC and the Kyoto Protocol. It is, however, clear that downstream effects will be felt much longer and with considerable time delay. Because of the long time scales of biogeochemical tracer transport from the Southern Ocean fertilization region to outcrop areas further north, an often substantial part of these effects is "in the pipeline" at any time, making the establishment of acceptable accounting 
schemes particularly difficult. If simulated OIF is stopped, transport of OIF-influenced waters will continue for many decades, affecting nutrient and oxygen levels and thereby new production as well as the production of other greenhouse gases such as $\mathrm{N}_{2} \mathrm{O}$. Not all of these side effects need to be labeled "negative" by common judgment schemes, though. Our model suggests, for example, that the extent of suboxic areas and of oceanic $\mathrm{N}_{2} \mathrm{O}$ emissions may actually decline during and after Southern Ocean iron fertilization (Figs. 4 and 7).

The joint consideration of oceanic, atmospheric and terrestrial carbon pools in our carbon-climate model reveals that, via the atmosphere, OIF will even impact the terrestrial carbon pools. For the assumptions used in current vegetation models (Friedlingstein et al., 2006), lower $\mathrm{CO}_{2}$ concentrations and lower surface temperatures lead to a net loss of carbon from the terrestrial biosphere to the atmosphere (and ocean). In the carbon-climate model employed here, about $8 \%$ of the carbon sequestered in the ocean by OIF within 100 years is derived from the land.

The size of this effect is, on the $100 \mathrm{yr}$ time scale considered, similar to the back flux of $\mathrm{CO}_{2}$ from the unfertilized regions to the atmosphere in response to atmospheric $\mathrm{CO}_{2}$ partial pressures lowered as a result of OIF. While it seems prudent to include this back flux in any hypothetical accounting scheme, we note that such a $\mathrm{CO}_{2}$ back flux from the atmosphere into the ocean also occurs when carbon is sequestered on land. A fair comparison of terrestrial and oceanic carbon sequestration options must therefore include a similar consideration of all carbon exchanged between the different carbon reservoirs that participate on the agreed time scale (so far, 100 years). A useful common accounting unit could be the amount of canceled emissions. For large-scale Southern Ocean iron fertilization, our model suggests that every ton carbon sequestered in the ocean compensates for 1.2 tons of carbon emissions to the atmosphere on a 100-year timescale. For OIF-induced changes in export production calibrated against natural iron fertilization experiments, simulated large-scale Southern Ocean iron fertilization induces an extra export of $139 \mathrm{GtC}$ over 100 years of continuous fertilization. This induces a global air-sea $\mathrm{CO}_{2}$ flux of $59 \mathrm{GtC}$, which in our model offsets $\mathrm{CO}_{2}$ emissions of some $70 \mathrm{GtC}$ over the 100-year period. This result shows that in order to objectively compare the efficiencies of different sequestration options, it is not sufficient to account for changes in only a single carbon pool, but rather to use a common metric like canceled $\mathrm{CO}_{2}$ emissions or global radiative forcing (Lenton and Vaugham, 2009).

With no drastic emission cuts on the horizon for the next few decades to come, decisions about large-scale carbon sequestration or climate engineering options may well have to be taken in the foreseeable future. Local and short-term monitoring schemes are probably unable to detect side effects such as leakage identified above. Information is needed on a global scale and for long time scales. Such informa- tion can in principle be provided by Earth System models which, however, are far from perfect and therefore introduce additional uncertainties into the assessment and potential accounting schemes. Uncertainty is not a new quality in our decision making processes per se, but we have to strive to reduce uncertainty by future research which, in our view, should consider carbon sequestration options such as OIF.

\section{Appendix A}

\section{Sensitivity to OIF-induced enhancement of phytoplankton growth rates}

The impact of large-scale Southern Ocean iron fertilization was parameterized via a local enhancement of the phytoplankton maximum growth rate. The main text used an enhancement calibrated such that simulated OIF induced changes in export production were in rough agreement with observations obtained at the natural iron fertilization sites at the Kerguelen Plateau and Crozet Islands (Blain et al., 2007; Pollard et al., 2009). Because we cannot currently rule out that further addition of iron to these naturally fertilized areas would further enhance export production, a number of sensitivity experiments were carried out. While the phytoplankton maximum growth rate of $0.13 \mathrm{day}^{-1}\left(\right.$ at $0{ }^{\circ} \mathrm{C}$ ) was doubled to $0.26 \mathrm{day}^{-1}$ in the fertilized areas in the standard fertilization experiment referred to in the main text, here we show results for experiments with maximum growth rates increased threefold to $0.39 \mathrm{day}^{-1}$, fivefold to $0.65 \mathrm{day}^{-1}$ and, in an attempt to generate depletion of macronutrients, to an artificially high rate of 10 day $^{-1}$.

While Southern Ocean surface nitrate concentrations decrease with increasing maximum phytoplankton growth rate, even the very extreme experiment with $\mu_{\max }(\mathrm{OIF})=10$ day $^{-1}$ does not fully deplete surface nitrate (Fig. A1). The total oceanic uptake of carbon increases from $58.6 \mathrm{GtC}$ by year 2110 in the standard OIF experiment to $98.8 \mathrm{GtC}$ in the experiment with $\mu_{\max }(\mathrm{OIF})=0.39 \mathrm{day}^{-1}$, $137 \mathrm{GtC}$ for $\mu_{\max }(\mathrm{OIF})=0.65 \mathrm{day}^{-1}$, and $169 \mathrm{GtC}$ for $\mu_{\max }(\mathrm{OIF})=10 \mathrm{day}^{-1}$ (Fig. A2). The latter value may be viewed as extreme upper level for the sequestration potential of Southern Ocean iron fertilization according to our model.

All conclusions obtained in the main text about sequestration efficiency and the relative contribution of atmospheric and terrestrial carbon to the OIF-induced oceanic carbon storage also apply to the sensitivity experiments. We here show results only for the "upper bound" experiment with $\mu_{\max }(\mathrm{OIF})=10$ day $^{-1}$ (Table A1, Fig. A3). 
Table A1. Model results for $\mu_{\max }=10$ day $^{-1}$ sensitivity experiment.

\begin{tabular}{|c|c|c|c|c|c|}
\hline & $1-y r$ OIF & 7-yr OIF & 10-yr OIF & $50-\mathrm{yr}$ OIF & $100-\mathrm{yr}$ OIF \\
\hline \multicolumn{6}{|c|}{ Cumulative OIF-induced export production, year $2110(\mathrm{GtC})$} \\
\hline fertilized area & 14.8 & 53.3 & 68.7 & 232 & 408 \\
\hline outside fertilized area & -2.4 & -7.8 & -9.8 & -23.2 & -26.4 \\
\hline global & 12.4 & 45.2 & 58.8 & 208 & 382 \\
\hline \multicolumn{6}{|c|}{ Cumulative OIF-induced air-sea $\mathrm{CO}_{2}$ flux, year $2110(\mathrm{GtC})$} \\
\hline fertilized area & 5.12 & 19.3 & 25.4 & 96.6 & 201 \\
\hline outside fertilized area & -1.79 & -5.7 & -7.4 & -22.0 & -31.3 \\
\hline global & 3.33 & 13.6 & 18.0 & 74.6 & 169 \\
\hline \multicolumn{6}{|c|}{ Ratio of cumul. OIF-induced air-sea flux to cumul. export production, year 2110} \\
\hline global & 0.27 & 0.30 & 0.31 & 0.36 & 0.44 \\
\hline \multicolumn{6}{|c|}{ OIF-induced terrestrial C loss, year $2110(\mathrm{GtC})$} \\
\hline global & 0.14 & 1.7 & 1.9 & 7.6 & 15.1 \\
\hline \multicolumn{6}{|c|}{ OIF-induced atmospheric $\mathrm{CO}_{2}$ decline, year 2110 (GtC) } \\
\hline global & 3.19 & 11.9 & 16.1 & 67.1 & 154 \\
\hline \multicolumn{6}{|c|}{ ratio of OIF-induced atmospheric $\mathrm{CO}_{2}$ decline to oceanic $\mathrm{CO}_{2}$ uptake, year 2110} \\
\hline global & 0.96 & 0.88 & 0.90 & 0.90 & 0.91 \\
\hline \multicolumn{6}{|c|}{ OIF-induced decline in atm. $p \mathrm{CO}_{2}$ and surface temperature, year 2110} \\
\hline$\Delta p \mathrm{CO}_{2}(\mu \mathrm{atm})$ & -1.52 & -5.69 & -7.70 & -32.1 & -73.3 \\
\hline$\triangle \mathrm{SAT}\left({ }^{\circ} \mathrm{C}\right)$ & -0.0085 & -0.023 & -0.034 & -0.141 & -0.273 \\
\hline
\end{tabular}

Results of "upper bound" experiment with very high maximum growth rate $\left(\mu_{\max }=10\right.$ day $\left.^{-1}\right)$ in iron fertilized area. Experiments use the SRES A2 emission scenario and start Ocean Iron Fertilization (OIF) everywhere south of $30^{\circ} \mathrm{S}$ in year 2011.
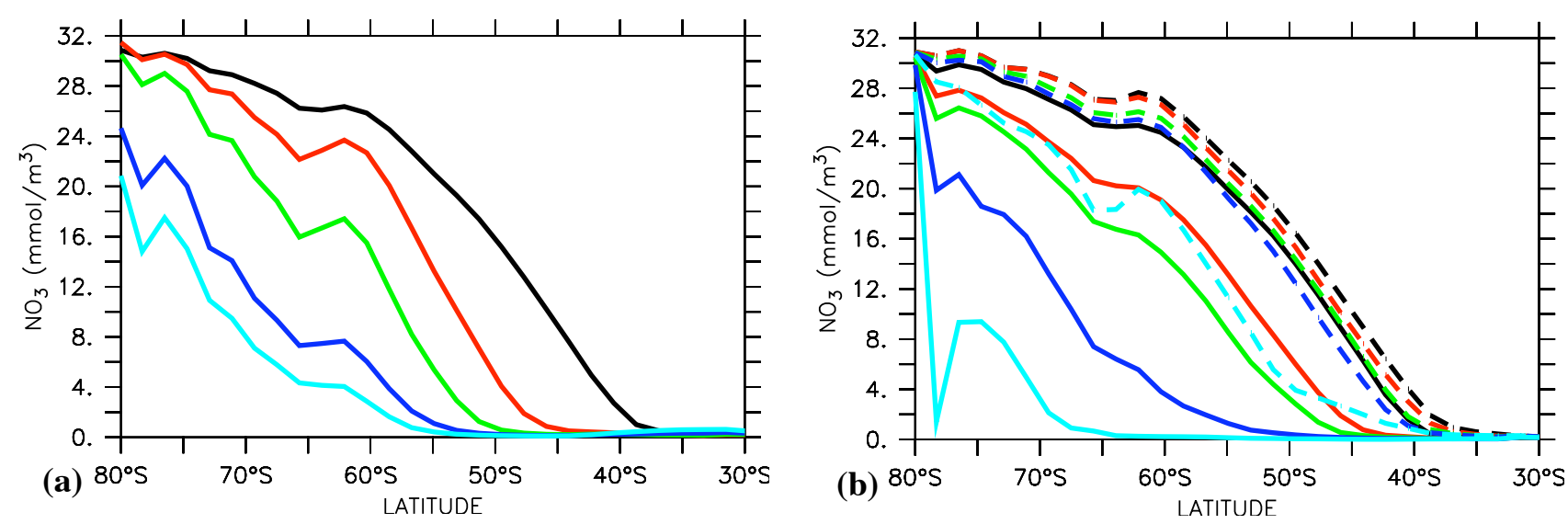

Fig. A1. (a) Zonally averaged simulated annual-mean surface nitrate concentrations in the control run (black) and in year 2110 of the standard OIF run of the main text (red) also shown in Fig. 2. Simulated surface nitrate concentrations of the sensitivity experiments are also shown for year 2110: OIF simulated by enhancing the phytoplankton maximum growth rate from 0.13 day $^{-1}$ to 0.39 day ${ }^{-1}$ (green), to $0.65 \mathrm{day}^{-1}$ (blue) and to the extreme case of $10 \mathrm{day}^{-1}$ (cyan). The latter experiment was performed in an attempt to simulate macronutrient depletion as assumed in earlier model studies (e.g., Sarmiento and Orr, 1991; Gnanadesikan et al., 2003). (b) Maximum (dashed) and minimum (solid) zonally averaged nitrate concentrations during the annual cycle in year 2010 of the control run (black) and the OIF runs using the same color code as in panel (a). As the figure reveals, even an extremely high growth rate is not sufficient to fully deplete nutrients in the seasonally light limited Southern Ocean. 


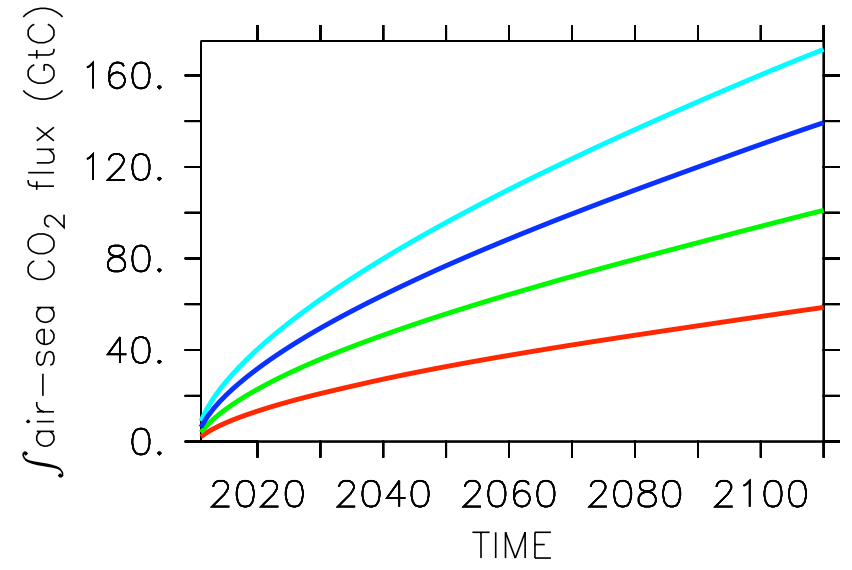

Fig. A2. Cumulative temporal integral of the net oceanic carbon uptake in response to simulated iron fertilization south of $30^{\circ} \mathrm{S}$ for the standard OIF experiment of the main text (red) and for the sensitivity experiments: OIF simulated by enhancing the phytoplankton maximum growth rate from $0.13 \mathrm{day}^{-1}$ to $0.39 \mathrm{day}^{-1}$ (green), to 0.65 day $^{-1}$ (blue) and to the extreme case of 10 day $^{-1}$ (cyan).

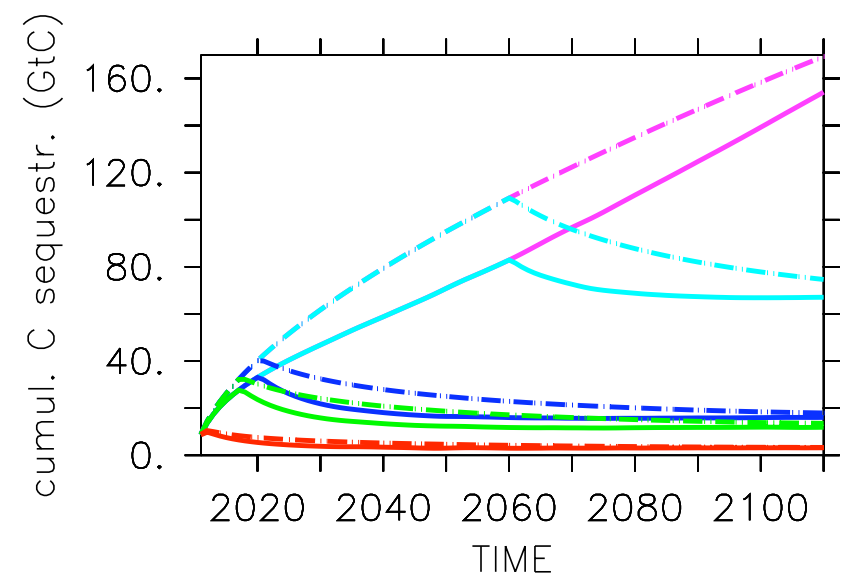

Fig. A3. As Fig. 11 of main text, but here for "upper bound" sensitivity experiment with $\mu_{\max }=10 \mathrm{day}^{-1}$ in iron fertilized area. Solid lines: Cumulative temporal integral of the fertilization-induced reduction in atmospheric $\mathrm{CO}_{2}$. Dashed lines: Cumulative temporal integral of the fertilization-induced change in global air-sea flux of $\mathrm{CO}_{2}$. Units are GtC.

Acknowledgements. We thank Michael Eby for technical support regarding the UVic model and acknowledge financial support through the DFG Project " $\mathrm{CO}_{2}$ mix", the Kiel Cluster of Excellence "The Future Ocean" and the BioAcid project of the Federal Ministry of Education and Research.

Edited by: J. Middelburg

\section{References}

Aumont, O. and Bopp, L.: Globalizing results from ocean in situ iron fertilization experiments, Global Biogeochem. Cy., 20, GB2017, doi:10.1029/2005GB002591, 2006.

Bange, H. W., Naqvi, S. W. A., and Codispoti, L. A.: The nitrogen cycle in the Arabian Sea, Prog. Oceanogr., 65, 61-71, 2005.

Bange, H. W., Bartell, U. H., Rapsomanikis, S., and Andreae, M. O.: Methane in the Baltic and North seas and a reassessment of the marine emissions of methane, Global Biogeochem. Cy., 13, 1127-1135, 1994.

Bates, T. S., Kelly, K. C., Johnson, J. E., and Gammon, R. H.: A reevaluation of the open ocean source of methane to the atmosphere, J. Geophys. Res., 101, 6953-6961, doi:10.1029/95JD03348, 1996.

Bishop, J. K. B., Wood, T. J., Davis, R. E., and Sherman, J. T.: Robotic observations of enhanced carbon biomass and export at $55^{\circ} \mathrm{S}$ during SOFeX, Science, 304, 417-420, 2004.

Blain, S., Quéguiner, B., Armand, L., Belviso, S., Bombled, B., Bopp, L., Bowie, A., Brunet, C., Brussaard, C., Carlotti, F., Christaki, U., Corbière, A., Durand, I., Ebersbach, F., Fuda, J.L., Garcia, N., Gerringa, L., Griffiths, B., Guigue, C., Guillerm, C., Jacquet, S., Jeandel, C., Laan, P., Lefèvre D., Lo Monaco, C., Malits, A., Mosseri, J., Obernosterer, I., Park, Y.-H., Picheral, M., Pondaven, P., Remenyi, T., Sandroni, V., Sarthou, G., Savoye, N., Scouarnec, L., Souhaut, M., Thuiller, D., Timmermans, K., Trull, T., Uitz, J., van Beek, P., Veldhuis, M., Vincent, D., Viollier, E., Vong, L., and Wagener, T.: Effect of natural iron fertilization on carbon sequestration in the Southern Ocean, Nature, 446, 1070-1075, 2007.

Boyd, P. W., and Ellwood, M. J.: The biogeochemical cycle of iron in the ocean, Nat. Geosci., 3, doi:10.1038/NGEO0964, 2010.

Boyd, P. W., Jickells, T., Law, C. S., Blain, S., Boyle, E. A., Buesseler, K. O., Coale, K. H., Cullen, J. J., de Baar, H. J. W., Follows, M., Harvey, M., Lancelot, C., Levasseur, M., Owens, N. P. J., Pollard, R., Rivkin, R. B., Sarmiento, J. L., Schoemann, V., Smetacek, V., Takeda, S., Tsuda, A., Turner, S., and Watson, A. J.: Mesocale iron enrichment experiments 1993-2005: synthesis and future directions, Science, 315, 612-617, 2007.

Boyd, P., Strzepek, R., Takeda, S., Jackson, G., Wong, C. S., McKay, R. M., Law, C., Kiyosawa, H., Saito, H., Sherry, N., Johnson, K., Gower, J., and Ramaiah, N.: The evolution and termination of an iron-induced mesoscale bloom in the northeast subarctic Pacific, Limnol. Oceanogr., 50, 1872-1886, 2005.

Buesseler, K. O., Doney, S. C., Karl, D. M., Boyd, P. W., Caldeira, K., Chai, F., Coale, K. H., de Baar, H. J. W., Falkowski, P. G., Johnson, K. S., Lampitt, R. S., Michaels, A. F., Naqvi, S. W. A., Smetacek, V., Takeda, S., and Watson, A. J.: Ocean fertilization - moving forwad in a sea of uncertainty, Science, 319, 162, 2008.

Cohen, Y. and Gordon, L.: Nitrous oxide production in the ocean, J. Geophys. Res., 84, 347-353, 1979.

Conkright, M. E., Garcia, H. E., O’Brien, T. D., Locarnini, R. A., Boyer, T. P., Stephens, C., and Antonov, J. I.: World Ocean Atlas 2001, Volume 4: Nutrients, edited by: Levitus, S., NOAA Atlas NESDIS 54, US Government Printing Office, Washington, DC, 392 pp., 2002.

Cox, P. M., Betts, R. A., Jones, C. D., Spall, S. A., and Totterdell, I. J.: Acceleration of global warming due to carbon-cycle feedbacks in a coupled climate model, Nature, 408, 184-187, 2000.

Cullen, J. J. and Boyd, P. W.: Predicting and verifying the intended 
and unintended consequences of large-scale ocean iron fertilization, Mar. Ecol.-Prog. Ser., 364, 295-301, 2008.

de Baar, H. J. W, Boyd, P. W., Coale, K. H., Landry, M. R., Tsuda, A., Assmy, P., Bakker, D. C. E., Bozec, Y., Barber, R. T., Brzezinski, M. A., Buesseler, K. O., Boyé, M., Croot, P. L., Gervais, F., Gorbunov, M. Y., Harrison, P. J., Hiscock, W. T., Laan, P., Lancelot, C., Law, C. S., Levasseur, M., Marchetti, A., Millero, F. J., Nishioka, J., Nojiri, Y., van Oijen, T., Riebesell, U., Rijkenberg, M. J. A., Saito, H., Takeda, S., Timmermans, K. R., Veldhuis, M. J. W., Waite, A. M., andWong, C.S.: Synthesis of iron fertilization experiments: From the iron age in the age of enlightenment, J. Geophys. Res., 110, C09S16, doi:10.1029/2004JC002601, 2005.

Denman, K. L., Brasseur, G., Chidhaisong, A., Ciais, P., Cox, P. M., Dickinson, R. E., Hauglustaine, D., Heinze, C., Jacob, D., Lohmann, U., Ramachandran, S., da Silva Dias, P. L., Wofsky, S. C., and Zhang, X.: Couplings Between Changes in the Climate System and Biogeochemistry, in: Climate Change 2007: The Physical Science Basis, Contribution of Working Group I to the Fourth Assessment Report of the Intergovernmental Panel on Climate Change, edited by: Solomon, S., Qin, D., Manning, M., Chen, Z., Marquis, M., Averyt, K. B., Tignor, M., and Miller, H. L., Cambridge University Press, Cambridge, UK and New York, NY, USA, 499-587, 2007.

Denman, K. L.: Climate change, ocean processes and ocean iron fertilization, Mar. Ecol.-Prog. Ser., 364, 219-225, 2008.

Friedlingstein, P., Cox, P., Betts, R., Bopp, L., von Bloh, W., Brovkin, V., Cadule, P., Doney, S., Eby, M., Fung, I., Bala, G., John, J., Jones, C., Joos, F., Kato, T., Kawamiya, M., Knorr, W., Lindsay, K., Matthews, H. D., Raddatz, T., Rayner, P., Reick, C., Roeckner, E., Schnitzler, K.-G., Schnur, R., Strassmann, K., Weaver, A. J., Yoshikawa, C., and Zeng, N.: Climate-carbon cycle feedback analysis: Results from the C4MIP model intercomparison, J. Climate, 19, 3337-3353, 2006.

Galbraith, E., D., Gnanadesikan, A., Dunne, J. P. and Hiscock, M. R.: Regional impacts of iron-light colimitation in a global biogeochemical model, Biogeosciences, 7, 1043-1064, 2010, http://www.biogeosciences.net/7/1043/2010/.

Gnanadesikan, A., Sarmiento, J. L., and Slater, R. D.: Effects of patchy ocean fertilization on atmospheric carbon dioxide and biological production, Global Biogeochem. Сy., 17, 1050, doi:10.1029/2002GB001940, 2003.

Güssow, K., Proelss, A., Oschlies, A., Rehdanz, K., and Rickels, W.: Ocean iron fertilization: Why further research is needed, Mar. Policy, 34, 911-918, 2010.

Hopkinson, B. M., Mitchell, B. G., Reynolds, R. A., Wang, H., Selph, K. E., Measures, C. I., Hewes, C. D., Holm-Hansen, O., and Barbeau, K. A.: Iron limitation across chlorophyll gradients in the southern Drake Passage: Phytoplankton responses to iron adition and photosynthetic indicators of iron stress, Limnol. Oceanogr., 52, 2540-2554, 2007.

Jin, X. and Gruber, N.: Offsetting the radiative benefit of ocean iron fertilization by enhancing $\mathrm{N}_{2} \mathrm{O}$ emissions, Geophys. Res. Lett., 30(24), 2249, doi:10.1029/2003GL018458, 2003.

Jin, X., Gruber, N., Frenzel, H., Doney, S. C., and McWilliams, J. C.: The impact on atmospheric $\mathrm{CO}_{2}$ of iron fertilization induced changes in the ocean's biological pump, Biogeosciences, 5, 385406, doi:10.5194/bg-5-385-2008, 2008.

Karl, D. M. and Tilbrook, B. D.: Production and transport of methane in oceanic particulate organic matter, Nature, 368, 732734, 1994.

Karl, D. M., Beversdorf, L. B., Björkman, K. M., Church, M. J., Martinez, A., and DeLong, E. F.: Aerobic production of methane in the sea, Nat. Geosci., 1, 473-478, 2008.

Law, C. S.: Predicting and monitoring the effects of large-scale ocean iron fertilization on marine trace gas emissions, Mar. Ecol.-Prog. Ser., 364, 282-288, 2008.

Law, C. S. and Ling, R. D.: Nitrous oxide flux and response to increased iron availability in the Antarctic Circumpolar Current, Deep-Sea Res. Pt. II, 48, 2509-2527, 2001.

Lenton, T. M. and Vaughan, N. E.: The radiative forcing potential of different climate geoengineering options, Atmos. Chem. Phys., 9, 5539-5561, doi:10.5194/acp-9-5539-2009, 2009.

Marinov, I., Gnadadesikan, A., Toggweiler, J. R., and Sarmiento, J. L.: The Southern Ocean biogeochemical divide, Nature, 441, 964-967, 2006.

Martin, J. H. and Fitzwater, S. E.: Iron deficiency limits phytoplankton growth in the north-east Pacific subarctic, Nature, 331, 341-343, 1988.

Measures, C. I., Landing, W.M., Brown, M. T., and Buck, C. S: High-resolution $\mathrm{Al}$ and $\mathrm{Fe}$ data from the Atlantic Ocean CLIVAR-CO $\mathrm{CO}_{2}$ repeat hydrography A16N transect: Extensive linkages between atmospheric dust and upper ocean geochemistry, Global Biogeochem. Cy., 22, GB1005, doi:10.1029/2007GB003042, 2008.

Meinshausen, M., Meinshausen, N., Hare, W., Raper, S. C. B., Frieler, K., Knutti, R., Frame, D. J., and Allen, M. R.: Greenhouse-gas emission targets for limiting global warming to $2{ }^{\circ} \mathrm{C}$, Nature, 458, 1158-1162, 2009.

Nevison, C., Butler, J. H., and Elkins, J. W.: Global distribution of $\mathrm{N}_{2} \mathrm{O}$ and the del $\mathrm{N}_{2} \mathrm{O}-\mathrm{AOU}$ yield in the subsurface ocean, Global Biogeochem. Cy., 17, GB1119, doi:10.1029/2003GB002068, 2003.

Orr, J. C., Fabry, V. J., Aumont, O., Bopp, L., Doney, S. C., Feely, R. A., Gnanadesikan, A., Gruber, N., Ishida, A., Joos, F., Key, R. M., Lindsay, K., Maier-Reimer, E., Matear, R., Monfray, P., Mouchet, A., Najjar, R. G., Plattner, G.-K., Rodgers, K. B., Sabine, C. L., Sarmiento, J. L., Schlitzer, R., Slater, R. D., Totterdell, I. J., Weirig, M.-F., Yamanaka, Y., and Yool, A.: Anthropogenic ocean acidification over the twenty-first century and its impact on calcifying organisms, Nature, 437, 681-686, 2005.

Oschlies, A.: Impact of atmospheric and terrestrial $\mathrm{CO}_{2}$ feedbacks on fertilization-induced marine carbon uptake, Biogeosciences, 6, 1603-1613, doi:10.5194/bg-6-1603-2009, 2009.

Oschlies, A., Schulz, K. G., Riebesell, U., and Schmittner, A.: Simulated 21st century's increase in oceanic suboxia by $\mathrm{CO}_{2}-$ enhanced biological carbon export, Global Biogeochem. Cy., 22, GB4008, doi:10.1029/2007GB003147, 2008.

Pollard, R. T., Salter, I., Sanders, R. J., Lucas, M. I., Moore, C. M., Mills, R. A., Statham, P. J., Allen, J. T., Baker, A. R., Bakker, D. C. E., Charette, M. A., Fielding, S., Fones, G. R., French, M., Hickman, A. E., Holland, R. J., Hughes, J. A., Jickells, T. D., Lampitt, R. S., Morris, P. J., Nédélec, F. H., Nielsdóttir, M., Planquette, H., Popova, E. E., Poulton, A. J., Read, J. F., Seeyave, S., Smith, T., Stinchcombe, M., Taylor, S., Thomalla, S., Venables, H. J., Williamson, R., and Zubkov, M. V.: Southern Ocean deep-water carbon export enhanced by natural iron fertilization, Nature, 457, 577-581, 2009. 
Ramaswamy, V., Boucher, O., Haigh, J., Hauglustaine, D., Haywood, J., Myhre, G., Nakajima, T., Shi, G. Y., and Solomon, S.: Radiative forcing of climate change, in: Climate Change 2001: The Scientific Basis, Contribution of Working Group I to the Third Assessment Report of the Intergovernmental Panel on Climate Change, edited by: Houghton, J. T., Ding, Y., Griggs, D. J., Noguer, M., van der Linden, P. J., Dai, X., Maskell, K., and Johnson, C. A., Cambridge Univ. Press, Cambridge, UK, 349416, 2001

Raven, J.: Predictions of Mn and Fe use efficiencies of phototrophic growth as a function of light availability for growth and of $\mathrm{C}$ assimilation pathway, New Phytol., 116, 1-18, 1990.

Rhee, T. S., Kettle, A. J., and Andreae, M. O.: Methane and nitrous oxide emissions from the ocean: A reassessment using basin-wide observations in the Atlantic, J. Geophys. Res., 114, D12304, doi:10.1029/2008JD011662, 2009.

Rickels, W., Rehdanz, K., and Oschlies, A.: Methods for greenhouse gas offsets accounting: A case study of ocean iron fertilization, Ecological Economics, 69, 2495-2509, 2010.

Royal Society: Geoengineering the climate: Science, governance and uncertainty, The Royal Society, London, 84pp, 2009.

Sabine, C. L., Feely, R. A., Gruber, N., Key, R. M., Lee, K., Bullister, J. L., Wanninkhof, R., Wong, C. S., Wallace, D. W. R., Tilbrook, B., Millero, F. J., Peng, T.-H., Kozyr, A., Ono, T., and Rios, A.. F.: The oceanic sink for anthropogenic $\mathrm{CO}_{2}$, Science, 305, 367-371, 2004.

Sarmiento, J. L. and Orr, J. C.: Three dimensional simulations of the impact of Southern Ocean nutrient depletion on atmospheric $\mathrm{CO}_{2}$ and ocean chemistry, Limnol. Oceanogr., 36, 1928-1950, 1991.

Sarmiento, J. L., Slater, R. D., Dunne, J., Gnanadesikan, A., and Hiscock, M. R.: Efficiency of small scale carbon mitigation by patch iron fertilization, Biogeosciences, 7, 3593-3624, doi:10.5194/bg-7-3593-2010, 2010.

Schmittner, A., Oschlies, A., Matthews, H. D., and Galbraith, E. D.: Future changes in climate, ocean circulation, ecosystems and biogeochemical cycling simulated for a business-as-usual $\mathrm{CO}_{2}$ emission scenario until $4000 \mathrm{AD}$, Global Biogeochem. Cy., 22, GB1013, doi:10.1029/2007GB002953, 2008.
Shi, D., Xu, Y., Hopkinson, B. M., and Morel, F. M. M.: Effect of ocean acidification on iron availability to marine phytoplankton, Science, 327, 676-679, 2010.

Strzepek, R. F., and Harrison, P. J.: Photosynthetic architecture differs in coastal and oceanic diatoms, Nature, 431, 689-692, 2004.

Sunda, W. G. and Huntsman, S. A.: Interrelated influence of iron, light and cell size on marine phytoplankton growth, Nature, 390, 389-392, 1997.

Suntharalingam, P., Sarmiento, J. L., and Toggweiler, J. R.: Global significance of nitrous-oxide production and transport from oceanic low-oxytgen zones: a modeling study, Global Biogeochem. Cy., 14, 1353-1370, 2000.

Trick, C. G., Bill, B. D., Cochlan, W. P., Wells, M. L., Trainer, V. L., and Pickell, L. D.: Iron enrichment stimulates toxic diatom production in high-nitrate, low-chlorophyll areas, P. Natl. Acad. Sci. USA, 107, 5887-5892, 2010.

UNFCCC: Report of the conference of the parties on its third session, held at Kyoto from 1 to 11 December 1997, Tech. rep., UNFCCC, 1997.

Walter, S., Peeken, I., Lochte, K., Webb, A., and Bange, H. W.: Nitrous oxide measurements during EIFEX, the European Iron Fertilization Experiment in the subpolar South Atlantic Ocean, Geophys. Res. Lett., 32, L23613, doi:10.1029/2005GL024619, 2005.

Weaver, A. J., Eby, M., Wiebe, E. C., Bitz, C. M., Duffy, P. B., Ewen, T. L., Fanning, A. F., Holland, M. M., MacFadyen, A., Matthews, H. D., Meissner, K. J., Saenko, O., Schmittner, A., Wang, H., and Yoshimori, M,: The UVic earth system climate model: Model description, climatology, and applications to past, present and future climates, Atmos. Ocean, 39, 361-428, 2001.

Weber, L., Völker, C., Oschlies, A., and Burchard, H.: Iron profiles and speciation of the upper water column at the Bermuda Atlantic Time-series Study site: a model based sensitivity study, Biogeosciences, 4, 689-706, doi:10.5194/bg-4-689-2007, 2007.

Wingenter, O. W., Haase, K. B., Strutton, P., Friedrich, G., Meinardi, S., Blake, D. R., and Rowland, F. S.: Changing concentrations of $\mathrm{CO}, \mathrm{CH}_{4}, \mathrm{C}_{5} \mathrm{H}_{8}, \mathrm{CH}_{3} \mathrm{Bt}, \mathrm{CH}_{3} \mathrm{I}$ and dimethyl sulfide during the Southern Ocean Iron Enrichment Experiments, P. Natl. Acad. Sci. USA, 101, 8537-8541, 2004. 